\title{
Temporal trend of drought and aridity indices in semi-arid pernambucano to determine susceptibility to desertification
}

\section{Tendência temporal dos índices de seca e de aridez no semiárido pernambucano para determinação da susceptibilidade a desertificação}

\author{
Fabianny Joanny Bezerra Cabral da Silva ${ }^{1}$ (D) \& José Roberto Gonçalves de Azevedo ${ }^{1}$ (i) \\ ${ }^{1}$ Universidade Federal de Pernambuco, Recife, PE, Brasil \\ E-mails: fjoanny@gmail.com (FJBCS),robdosport@hotmail.com (JRGA),
}

Received: September 30, 2019 - Revised: April 07, 2020 - Accepted: May 05, 2020

\begin{abstract}
In semi-arid regions, the use of drought and aridity indices in order to establish diagnoses and prognoses that help in water resources management is crucial, above all, for the evaluation of long-term water availability, and monitoring hydrological extreme events. Therefore, the aim of this study was to evaluate the trends of extreme events to determine susceptibility to desertification in the Brígida river basin, by Drought (RAI, SPI and PDSI) and Aridity (MIA, AI and AI $_{\text {ASD }}$ ) Indices. The results of these indices submitted to statistical analysis (Tukey Test) and to the evaluation of the climate trend (TREND software). The Tukey Test indicated that the PDSI and RAI method are the most suitable for drought analysis, while AI is most appropriate for aridity. The results indicated that regardless of the indices employed, the stations presented significant results in the trend analysis, suggesting intensification of these events over time. Therefore, concluded that drought and aridity indices could help water resources management by managing bodies, indicating the evolution of extreme hydrological phenomena, suggesting the adoption of preventive and mitigating actions regarding the use of water priority. In conclusion, these indices can be used as a tool for indicating areas susceptible to the desertification process.
\end{abstract}

Keywords: Rainfall Anomaly Index (RAI); Standardized Precipitation Index (SPI); Palmer Drought Severity Index (PDSI); Martonne's Aridity (MIA); Thornthwaite's Aridity (AI); Brígida river basin.

\section{RESUMO}

Em regiões semiáridas, a utilização de índices de seca e aridez a fim de estabelecer diagnósticos e prognósticos que ajudem na gestão dos recursos hídricos é crucial, sobretudo, para a avaliação de disponibilidade hídrica em longo prazo, e monitoramento de eventos hidrológicos extremos. Diante disso, o objetivo do presente estudo foi avaliar as tendências de eventos extremos para determinar a susceptibilidade à desertificação, na bacia do rio Brígida, mediante o uso de índices de Seca (RAI, SPI e PDSI) e de Aridez (MIA, AI e AI $\left.{ }_{A S D}\right)$. Os resultados desses índices foram submetidos a análise estatística por meio do Teste de Tukey e submetidos a avaliação da tendência climática por meio de aplicativo (TREND). O Teste de Tukey indicou que o método PDSI e RAI são os mais indicados para a análise de seca, enquanto que o AI é mais apropriado para a aridez. Os resultados indicaram que independente dos índices empregados, os postos apresentaram resultados significativos na análise de tendência, sugerindo intensificação desses eventos ao longo do tempo. Diante disso, conclui-se que os índices de seca e de aridez podem auxiliar na gestão dos recursos hídricos pelos órgãos gestores, indicando a evolução dos fenômenos hidrológicos extremos, sugerindo a adoção de ações preventivas e mitigadoras quanto ao uso prioritário da água. Além disso, esses índices podem ser empregados como ferramenta para indicação de áreas susceptíveis ao processo de desertificação.

Palavras-chave: Índice de Anomalia de Chuva (RAI); Índice de Precipitação Padronizado (SPI); Severidade de Seca de Palmer (PDSI); Aridez de Martonne (MIA); Aridez de Thornthwaite (AI); bacia do rio Brígida. 
Temporal trend of drought and aridity indices in semi-arid pernambucano to determine susceptibility to desertification

\section{INTRODUCTION}

Dry lands as well-known are the arid, semi-arid and subhumid dry lands covering about $41 \%$ of the continents and islands of the planet and house about a third of the world's population. In these areas are also located most of the poverty, especially in Africa, Asia and Latin America (Centro de Gestão e Estudos Estratégicos, 2016). Thus, it turns out that the problem of dry lands is not, a problem only in the Northeast region or Brazilian semi-arid, but a global challenge.

In Brazil, the Northeast region is formed by nine states (Alagoas, Bahia, Ceará, Marahão, Paraíba, Pernambuco, Piauí, Rio Grande do Norte and Sergipe), which together have an estimated population of $53,081,950$ inhabitants which corresponds to $28 \%$ of the Brazilian population (Instituto Brasileiro de Geografia e Estatística, 2010).

According to Marengo (2008), the Northeast region occupies $1,600,000 \mathrm{~km}^{2}$ from the Brazilian territory, $62 \%$ of which are affected by drought polygon and $940,000 \mathrm{~km}^{2}$ inserted in the semi-arid region, where approximately 30 million people live, equivalent to $15 \%$ of the national population. According to Ribeiro \& Santos (2016), the Brazilian semi-arid region is the most populous dry region in the world, which makes the threat to water, food and energy security a constant factor due to the repeated occurrence of droughts.

The Brígida river basin is located in the semi-arid region in the Brazilian Northeast, which is defined by three criteria: annual average rainfall of less than $800 \mathrm{~mm}$; Aridity index $\leq 0.5$; and drought risk greater than $60 \%$; according to Ordinance $\mathrm{n}^{\circ}$ 89 and $\mathrm{n}^{\circ} 01$ of the Ministry of National Integration published on March 16, 2005 (Brasil, 2005).

In addition to these characteristics, the Northeastern semiarid region also has frequent droughts that can be characterized by the absence, scarcity, low frequency and limited quantity, as well as the simple poor distribution of rainfall during the wet period. A succession of years with rainfall below the long-term average value is not rare (Brasil, 2009).

According to the historical records of extreme hydrological events, of the Centre for Studies and Research in Engineering and Civil Defense (Universidade Federal de Santa Catarina, 2015) there were 124 periods of drought in the northeast from the 16th century to the 21 st century. It is important to emphasize that most of the severe droughts recorded in the northeast have been due to the occurrence of the atmospheric oceanic phenomenon El Niño. This phenomenon warms the ocean through a homonymous current and weakens the trade winds that transport moisture, which favouring variations in rainfall distribution in tropical regions of middle and high latitudes (Centro de Previsão de Tempo e Estudos Climáticos, 2017; Oliveira, 2001).

Besides drought, the aridity in the region is another factor that contributes significantly to the low water availability of the region of the Brígida river basin. According to Mainguet (1998), the aridity represents the climate of a region and its consequences as characterized by little precipitation, poor vegetation and high temperature associated with a hydrological deficit.

According to Intergovernmental Panel on Climate Change (2019), desertification is land degradation in arid, semi-arid and dry sub-humid areas, commonly known as dry lands, resulting from many factors, including human activities and climatic variations. According to United Nations Convention to Combat Desertification (2014), the reach and intensity of desertification has been increasing in some dry land areas over the last 5 decades.

This fact is quite worrying, because according to the Intergovernmental Panel on Climate Change (2014) a reduction of up to $22 \%$ in precipitation patterns in Northeastern Brazil is expected, associated with a reduction in the order of $24.6 \%$ in the flow of the São Francisco river, where the study area is a tributary sub-basin.

Allied to this, expected that large metropolitan regions and small municipalities, in Northeastern Brazil, will be directly influenced by climatic phenomena such as temperature extremes, droughts, floods, landslides, etc.

Projections indicate that desertification already affects about $13 \%$ of the Brazilian semi-arid region and the scenario worsens in areas susceptible to Desertification (ASD) established by the Ministry of the Environment (Brasil, 2007), where desertification already reaches an equivalent to 1,488 municipalities, 32 million inhabitants and $85 \%$ of the country's poor people, according to Buriti \& Barbosa (2018).

The scenarios for the Northeast in the medium and long term are not encouraging at all, and the large number of records of extreme hydrological events in the region, highlights the size of the importance of monitoring tools and mitigating their effects.

Maliva \& Missimer (2012) point out that drought and aridity indices have high importance in tracking the effects of climate change on local water resources, provided that reliable and extensive data series are used to identify local changes in index values over time.

In addition to these authors, several international bodies such as the World Meteorological Organization (WMO), United Nations Educational, Scientific and Cultural Organization (UNESCO), United Nations Convention to Combat Desertification (UNCCD) and Organization United Nations (UN) have now recommended the use of various drought and aridity indices for monitoring semi-arid regions and verifying desertification susceptibility.

Among several methods, the most used are the Rainfall Anomaly (RAI), Standardized Precipitation (SPI), and Palmer Drought Severity (PDSI) indices for drought evaluation; and the Martonne's Aridity (MIA) and Thornthwaite's Aridity (AI), due to ease of application and reliability. In analyse of hydrological fluctuations international climate research agencies recommend the use Percent of Normal, Deciles and Surface Water Supply Index (SWSI).

In this context, the scientific community has been developing numerous research on the occurrence of droughts and aridity in the semi-arid regions in Brazil and around the world. Examples of these studies were conducted by Felix (2015); Eshetu et al. (2016); Guenang \& Kamga (2014); Pramudya et al. (2019); Rodrigues et al. (2018); Chowdhury (2018); Moral et al. (2017); Dabaghi \& Manjari (2017); Fundação Oswaldo Cruz (2017); Jesus et al. (2019) and Gao et al. (2015).

All these studies denote the importance of monitoring extreme hydrological events in the current context, especially through the effects of climate change, which reduce precipitation, 
increase aridity and increase susceptibility to the process of desertification, making dry lands unproductive.

Therefore, the use of tools such as drought and aridity indices can contribute significantly to decision-making by management bodies for the water resources management, especially in semi-arid regions. This premise is because these indices can indicate whether dry periods are intensifying, requiring planning of preventive and mitigating actions regarding the priority use of water. Similarly, the evolution of aridity can indicate the areas susceptible to the desertification process, being used by stakeholders to implement actions and programs aimed at the proper use of the soil, in a sustainable way

Thus, the present work aims to analyse from drought and aridity indices, an increase in extreme hydrological events, such as droughts, is occurring in the period 1961-2016, and whether there is a change in the historical trend, as well as an increased of aridity and susceptibility to desertification in the Brígida river basin.

\section{MATERIAL AND METHODS}

\section{Study area}

The hydrographic basin of the Brígida river, called the water planning unit (UP-11) by the State plan for water resources of Pernambuco (1998) is understood to be between the coordinates $07^{\circ} 19^{\prime} 02^{\prime \prime}$ and $08^{\circ} 36^{\prime} 32^{\prime \prime}$ Latitude South, and 39 $17^{\prime} 33^{\prime \prime}$ and $40^{\circ} 43^{\prime} 06^{\prime \prime}$ Longitude West (Figure 1). The basin has an area of $13,560.90 \mathrm{~km}^{2}$, passing through the territory of 15 (fifteen) municipalities, of which 08 (eight) have the headquarters located in the basin.

The main watercourse of the Brígida basin rises in the municipality of Exú, in the Chapada do Araripe at an altitude of 800 meters. The river travels $129 \mathrm{~km}$ until it flows into the São Francisco river. The main tributaries, on the right bank, are the creek of the Tabocas, Alecrim Creek, Gravatá Creek and São Pedro River; and from the left bank, the creek of the monkeys, the creek of Espírito Santo and the creek of Antônio. All watercourses in the basin, including the main river, have intermittent flow regimes and torrential regime during the rainy season.

The climate of the Brígida river basin is the BSh type of Köppen, a hot semi-arid climate, characterized by the scarcity of rainfall and irregularity in the distribution of precipitation, associated with low nebulosity, strong insolation, with a high evaporation rate that contributes significantly to the risk of salinization of water bodies (Empresa Brasileira de Pesquisa Agropecuária, 2016).

According to Pernambuco (2006), the average monthly temperature in the basin is in the range of 24.4 to $28.7^{\circ} \mathrm{C}$, with an annual average around $27^{\circ} \mathrm{C}$. The average annual rainfall of the Brígida river basin varies from $700 \mathrm{~mm}$, near the Chapada, to $400 \mathrm{~mm}$, as it gets closer to the São Francisco river. The rainy season goes from January to May, receiving about $80 \%$ of the average annual rainfall, followed by a dry period that comprises the other months of the year. The average annual evaporation (evapotranspiration) is of the order of $3,157.3 \mathrm{~mm}$, and the average annual relative humidity is $59.4 \%$, according to the data of the Normal climatological of Cabrobó in the period of 1961-1990 (Instituto Nacional de Meteorologia, 2009).

\section{Data series}

Precipitation, relative humidity, maximum soil retention capacity and temperature were used to estimate the dry and aridity indices. For precipitation, 38 out of 60 selected pluviometric stations registered in the Hydrological Information System - HIDROWEB were used (Agência Nacional de Águas, 2017). It is important to emphasize that of the 15 municipalities that compose the basin only 13 of them have data in the HIDROWEB, because the municipalities of Santa Cruz and Santa Filomena do not have pluviometric stations registered in their territory.

The temperature and relative humidity data were extracted from the series of conventional meteorological Stations of the National Institute of Meteorology (Instituto Nacional de Meteorologia, 2017) of Cabrobó (82886), Ouricuri (82753) and Petrolina (82983), data from the last two stations is being used only to fill out failures of Cabrobó station data.

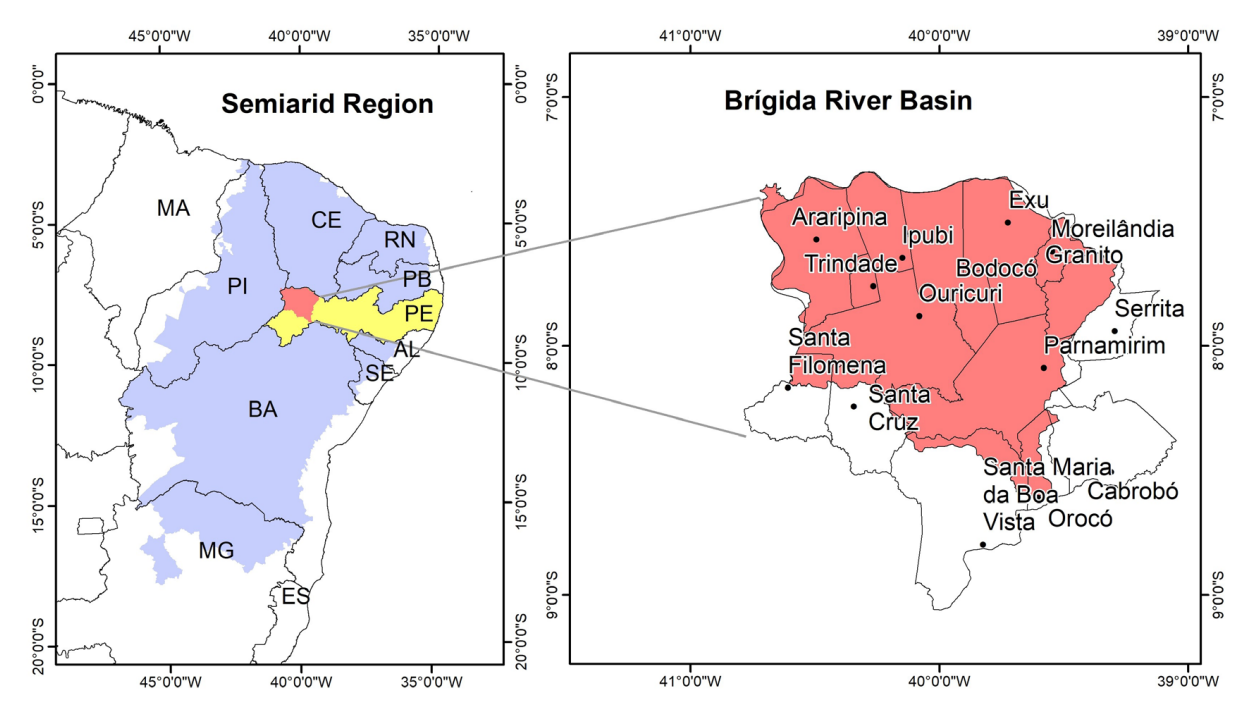

Figure 1. Location of the Brígida river basin. 
All data regarding precipitation, relative humidity and temperature were submitted to the process of data gap filling, through an application developed by Azevedo (2017), which employs the regional weighting methods with regression, regional weighting, simple linear regression and regional vectors, recommended by Agência Nacional de Águas (2012) and Tucci (2013). For all analyses, the data period from January 1961 to December 2016 adopted because this made it possible to compare the data series from two different periods. These periods were 1961-1990, corresponding to a period of a normal climatological standard (consecutive series of 30 years) and 1991-2016, which coincides with the period of a provisional normal (series of at least 10 years), according to World Meteorological Organization (1989).

The values of maximum water retention capacity per soil class were taken from the Pedoclimatic Zoning of the State of Pernambuco (Agência Estadual de Planejamento e Pesquisas de Pernambuco, 1987) extracted in a weighted manner, by soil class, using the coefficients of the area of influence of each pluviometric station, in the area of the Brígida river basin, with the aid of geoprocessing software.

\section{Drought indices}

\section{1) Rainfall Anomaly Index (RAI):}

Developed by Rooy (1965), RAI aims to identify in the precipitation series extreme anomalies of positive order (Equation 1) and negative (Equation 2) and, thus, to classify dry and humid periods.

$$
\begin{aligned}
& R A I=3\left[\frac{(p-\bar{p})}{\bar{m}-\bar{p}}\right] \\
& R A I=-3\left[\frac{(p-\bar{p})}{\bar{x}-\bar{p}}\right]
\end{aligned}
$$

where: $p$ is the monthly precipitation $(\mathrm{mm}) ; \bar{p}$ is the average monthly rainfall of the historical series $(\mathrm{mm}) ; \bar{m}$ is the average of the 10 highest monthly values in the historical series ( $\mathrm{mm}) ; \bar{x}$ is the average of the 10 monthly lower values of the historical series ( $\mathrm{mm}$ ).

Estimated RAI values sorted into categories (Table 1).

\section{2) Standardized Precipitation Index (SPI):}

Created by McKee et al. (1993) to quantify precipitation deficit on multiple time scales in order to analyse the impact of drought on the availability of water sources. This method is based on the long-term precipitation record (at least 30 years) being adjusted through the gamma distribution, which later converts into a normal distribution with an average of zero and unit variance.

A set of average periods was selected to determine a set of time scales from the period $j$ months, where $j$ is $3,6,12,24$, or 48 months. The precipitation in the SPI used to calculate the current percentage of average precipitation for the period of i months, which serves to monitor both dry and rainy periods. In the present study, adopted the period of 48 months, because the long-term SPI shows changes in precipitation, related to long-term droughts.

The gamma distribution defined by the probability density function given by Equation 3.

$$
g(x)=\frac{1}{\Gamma(\alpha) \beta \alpha} X^{\alpha-1} e^{\frac{-X}{\beta}}
$$

where: $\alpha>0$ is the shape parameter (adimensional); $\beta>0$ is the scale parameter $(\mathrm{mm}) ; \mathrm{X}>0$ is the total precipitation $(\mathrm{mm}) ; \Gamma(\mathrm{X})$ is the gamma function obtained by the formula $\Gamma(\alpha)=\int_{0}^{\infty} y^{\alpha-I} \cdot e^{-y} \cdot d y$.

According to McKee et al. (1993), a dry event for the specific time scale starts in the first month of the series analysed with negative value and when the subsequent sum of the SPI reaches the value $\leq-1.0$, and ends when the continuous sum of the SPI returns to the value zero or positive. The SPI values were categorized according to the Table 2.

\section{3) Palmer Drought Severity Index (PDSI):}

Elaborated by Palmer (1965), the PDSI aims to provide standardised measurements of soil moisture conditions so that comparisons between the duration of a drought or a period of moisture can be made. Equation 4 used to calculate the PDSI.

$$
P D S I_{I}=0.897 . P D S I_{i-1}+\left(\frac{Z_{i}}{3}\right)
$$

where: $i$ is the month of interest of the index; $Z_{i}$ is the moisture anomaly index obtained by Equation 5 .

$$
Z_{i}=\left(P_{i}-\overline{P_{i}}\right) \cdot K_{i}
$$

where: $P_{i}$ is the precipitation observed in the month $i$; $K_{i}$ is the standardization constant; $\bar{P}_{i}$ is the appropriate climatological precipitation for local conditions in the month $i$ obtained with Equation 6.

$$
\bar{P}_{l}=\alpha_{i} E T P_{i}+\beta_{i} P R_{i}+\gamma_{i} P R O_{i}-\delta_{i} P L_{i}
$$

where: ETP is the potential evapotranspiration; $P R$ is the potential refill of soil moisture; $P R O$ is the potential surface runoff; $P L$ is the potential loss of soil moisture. The values of PR, PRO and PL were obtained through the Equations 7, 8 and 9.

$$
P R=A W C-S^{\prime}
$$

Table 1. RAI categories.

\begin{tabular}{ccc}
\hline Categories & RAI & Description \\
\hline R0 & $\geq 4.0$ & Extremely wet \\
R1 & $\geq 2.0$ and $<4.0$ & Very wet \\
R2 & $>0$ and $<2.0$ & Wet \\
R3 & $<0$ and $>-2.0$ & Dry \\
R4 & $\leq-2.0$ and $>-4.0$ & Very dry \\
R5 & $\leq-4.0$ & Extremely dry \\
\hline
\end{tabular}

Source: Rooy (1965).

Table 2. SPI categories.

\begin{tabular}{ccc}
\hline Categories & SPI & Description \\
\hline S0 & $\geq 2.0$ & Extremely wet \\
S1 & 1.5 to 1.99 & Very wet \\
S2 & 1.0 to 1.49 & Moderately wet \\
S3 & -0.99 to 0.99 & Near normal \\
S4 & -1.0 to -1.49 & Moderately dry \\
S5 & -1.5 to -1.99 & Severely dry \\
S6 & $\leq-2.0$ & Extremely dry \\
\hline
\end{tabular}

Source: World Meteorological Organization (2012). 
$P R O=A W C-P R=S^{\prime}$

$P L=P L_{S}-P L_{u}$

where: AWC is the water capacity per soil class obtained from the Pedoclimatic Zoning of the State of Pernambuco (Agência Estadual de Planejamento e Pesquisas de Pernambuco, 1987). $S^{\prime}$ is the amount of available moisture in both layers $\left(S_{S}\right.$, is available moisture stored in surface layer and $\mathrm{S}_{\mathrm{u}}$ is available moisture stored in underlying levels). $\mathrm{PL}_{\mathrm{S}}$ is the potential loss of soil moisture from the surface layer $\left(\mathrm{PL}_{\mathrm{S}}=\mathrm{PE}\right)$. $\mathrm{PE}$ is potential evapotranspiration for the month. $\mathrm{PL}_{\mathrm{u}}$ is the potential loss of soil moisture from the underlying soil, where $\mathrm{PL}_{\mathrm{u}}=\left(\mathrm{PE}-\mathrm{PL}_{\mathrm{S}}\right) . \mathrm{S}_{\mathrm{u}}{ }_{\mathrm{u}} / \mathrm{AWC}$.

The coefficients $\alpha, \beta, \gamma$ and $\delta$ were obtained through the monthly water balance developed by Hargreaves \& Christiansen (1974), aided by a computer program developed by Faeirstein (2019), where Equation 10 was used.

$\alpha=\frac{E T R}{E T P} \quad \beta=\frac{R}{P R} \quad \gamma=\frac{\overline{R O}}{P R O} \quad \delta=\frac{L}{P L}$

where: $\overline{E T R}$ is the actual evapotranspiration; $\bar{R}$ is the recharge; $\overline{R O}$ is the superficial runoff; $\bar{L}$ is soil moisture loss. The values of $\bar{R}$, $\overline{R O}$ and $\bar{L}$ were obtained based on the Equations 11, 12 and 13 .

$\bar{R}=\Delta S s+\Delta S u$

$\overline{R O}=\left(S^{\prime}+P-P E T-A W C\right) * r_{f a c t o r}$

$\bar{L}=L_{S}+L_{u}$

where: $r_{\text {factor }}$ is the factor that indicates the percentage of water available for runoff. For this work, a factor equal to 1 was adopted, indicating that there are no obstructions in the passage of water for draining.

To determine potential evapotranspiration ( $\mathrm{mm} / \mathrm{month}$ ), the Hargreaves \& Christiansen (1974) method was adopted, as it was developed especially for the Brazilian semi-arid region, where the study area is located (Equation 14).

$E T P=F . T F . C H$

where: $\mathrm{F}$ is the monthly dependent factor of latitude ( $\mathrm{mm} / \mathrm{month}$ ), $\mathrm{TF}$ is the average temperature in ${ }^{\circ} \mathrm{F}$ and $\mathrm{CH}$ is the monthly average relative humidity correction factor.

The regional standardization constant $\left(K_{i}\right)$ created by Palmer (1965) adapted by Limeira et al. (2006), according to the local condition using Equation 15 to 17.

$$
\begin{aligned}
K_{i} & =\left(21.87 . \bar{K}_{i}\right) / \sum_{j=1}^{12}\left|P_{j}-\bar{P}_{j}\right| K_{j} \\
\bar{K}_{i} & =1.5 \log _{10}\left[\frac{\left(K_{j}+2.8\right)}{\left|P_{i}-\bar{P}_{i}\right|} \cdot 25.4\right]+0.5 \\
K_{j} & =\frac{\left(\overline{E T R}_{i}+\bar{R}_{i}+\overline{R O}_{i}\right)}{\left(\bar{P}_{i}+\bar{L}_{i}\right)}
\end{aligned}
$$

where: $K_{j}$ is the ratio between demand and moisture supply.
In the water balance, the soil field capacity values taken from the Pedoclimatic Zoning of the State of Pernambuco were used (Agência Estadual de Planejamento e Pesquisas de Pernambuco, 1987). The PDSI were classified according to Table 3.

\section{Aridity indices}

1) Martonne's Aridity (MIA)

Created by Martonne (1926) to evaluate the aridity of a given site using only precipitation and temperature data, are used to estimate the monthly aridity index using Equation 18.

$$
M I A=\frac{12 \cdot P_{i}}{T_{i}+10}
$$

where: $P_{i}$ is the monthly precipitation (mm) of the month analysed; $T_{i}$ is the monthly temperature $\left({ }^{\circ} \mathrm{C}\right)$ of the month analysed.

Estimated MIA values were characterized according to Table 4.

\section{2) Thornthwaite's Aridity (AI)}

Developed by Thornthwaite (1948) to quantify the deficit or surplus of water in a given region using Equation 19.

$$
A I=100 \cdot \frac{P}{E T P}
$$

where: $P$ is the monthly precipitation $(\mathrm{mm}) ; E T P$ is the potential monthly evapotranspiration ( $\mathrm{mm} / \mathrm{month}$ ) estimated using the Hargreaves \& Christiansen (1974) method, through Equation 14. The AI values classified according to the Table 5 .

Table 3. PDSI categories.

\begin{tabular}{ccc}
\hline Categories & PDSI & Description \\
\hline P1 & $\geq 4.0$ & Extremely wet \\
P2 & 3.0 to 3.99 & Very wet \\
P3 & 1.0 to 2.99 & Moderately wet \\
P4 & 1.0 to 1.99 & Slightly wet \\
P5 & 0.50 to 0.99 & Incipient wet spell \\
P6 & 0.49 to -0.49 & Near normal \\
P7 & -0.50 to -0.99 & Incipient drought \\
P8 & -1.0 to -1.99 & Mild drought \\
P9 & -2.0 to -2.99 & Moderate drought \\
P10 & -3.0 to -3.99 & Severe drought \\
P11 & $\leq-4.0$ & Extreme drought \\
\hline
\end{tabular}

Table 4. MIA categories.

\begin{tabular}{ccc}
\hline Categories & MIA & Description \\
\hline M0 & $>60$ & Humidity above normal \\
M1 & $>30$ and $\leq 60$ & Wet \\
M2 & $>20$ and $\leq 30$ & Humidity below normal \\
M3 & $>15$ and $\leq 20$ & Semi-arid \\
M4 & $>5$ and $\leq 15$ & Arid \\
M5 & $\geq 0$ and $\leq 5$ & Extremely Arid \\
\hline
\end{tabular}

*The last Class (M5) was adapted to $\geq 0$ and $\leq 5$, instead of $>0$ and 5. Source: Martonne (1926) adapted by the authors. 
3) Aridity Index of Areas Susceptible to Desertification $\left(\mathrm{AI}_{\mathrm{ASD}}\right)$

In addition to the aforementioned AI classification, the categorization proposed by the United Nations Environment Program (PNUMA) developed by United Nations Educational, Scientific and Cultural Organization (1979), was made to monitor the evolution of Areas Susceptible to the Desertification Process (ASD) in the world, given that Brazil has been a signatory to the United Nations Convention to Combat Desertification (UNCCD) since 1997.

According to this treaty, the degree of aridity of a region depends on the amount of water coming from the rain and the maximum possible loss of water by potential evapotranspiration (Equation 20).

$$
A I_{A S D}=\frac{P}{E T P}
$$

where: $A I_{A S D}$ is the rate of aridity of areas susceptible to desertification; $P$ is the monthly precipitation $(\mathrm{mm})$; and ETP is the potential monthly evapotranspiration ( $\mathrm{mm} / \mathrm{month}$ ).

Table 5. AI categories.

\begin{tabular}{ccc}
\hline Categories & AI & Description \\
\hline A0 & $\geq 0$ and $\leq 16.7$ & Little or no water deficiency \\
A1 & $>16.7$ and $\leq 33.3$ & Moderate Hydric deficiency \\
A2 & $>33.3$ & Great water deficiency \\
\hline
\end{tabular}

Source: Thornthwaite (1948).

Table 6. Classification of the $\boldsymbol{A I}_{\boldsymbol{A S D}}$ proposed by United Nations Educational, Scientific and Cultural Organization (1979) and adapted by the CONAMA Resolution.

\begin{tabular}{ccc}
\hline Categories & AI $_{\text {ASD }}$ & Zone \\
\hline AI1 & $\leq 0.05$ & Hyper-arid \\
AI2 & $>0.05$ and $\leq 0.20$ & Arid \\
AI3 & $>0.20$ and $\leq 0.50$ & Semi-arid \\
AI4 & $>0.50$ and $\leq 0.65$ & Dry Subhumid \\
AI5 & $>0.65$ & Subhumid Humid \\
\hline \multicolumn{2}{l}{ Source: CONAMA Resolution $\mathrm{n}^{\circ} 238$ of 1997 (Brasil, 2012). }
\end{tabular}

Table 7. Comparison analysis of the drought and aridity indices.

\begin{tabular}{|c|c|c|c|}
\hline Indices & Input Data & Advantage & $\begin{array}{c}\text { Disadvantage } \\
\end{array}$ \\
\hline $\mathrm{RAI}^{1}$ & Rainfall & $\begin{array}{l}\text { - Uses only a single type of input data } \\
\text { - It can identify positive and negative } \\
\text { anomalies in the rainfall regime }\end{array}$ & $\begin{array}{l}\text { It does not take into account other factors } \\
\text { that can influence the rainfall regime, such as } \\
\text { temperature, evapotranspiration, etc. }\end{array}$ \\
\hline $\mathrm{SPI}^{1}$ & Rainfall & $\begin{array}{l}\text { - Uses only a single type of input data. } \\
\text { - It can identify the beginning and end of } \\
\text { the dry season. }\end{array}$ & $\begin{array}{l}\text { - It does not take into account other factors } \\
\text { that can influence the rainfall regime, such as } \\
\text { temperature, evapotranspiration, etc. } \\
\text { - Requires a minimum of } 30 \text { years of data } \\
\text { series. }\end{array}$ \\
\hline PDSI $^{1}$ & $\begin{array}{l}\text { Rainfall, evapotranspiration, } \\
\text { moisture of soil, recharge, water } \\
\text { balance }\end{array}$ & $\begin{array}{l}\text { - It can identify the beginning and end of } \\
\text { the dry season. } \\
\text { - Uses a variety of data that makes the index } \\
\text { more sensitive to hydrological changes. }\end{array}$ & $\begin{array}{l}\text { Requires a wide variety of input data that is not } \\
\text { always available. }\end{array}$ \\
\hline MIA $^{2}$ & Rainfall and temperature & - Uses only two types of input data & - \\
\hline $\mathrm{AI}^{2}$ & Rainfall and evapotranspiration & - Uses only two types of input data & $\begin{array}{l}\text { Evapotranspiration data are not always available } \\
\text { for the study region. }\end{array}$ \\
\hline $\mathrm{AI}_{\mathrm{ASD}}^{2}$ & Rainfall and evapotranspiration & - Uses only two types of input data & $\begin{array}{l}\text { Evapotranspiration data are not always available } \\
\text { for the study region. }\end{array}$ \\
\hline
\end{tabular}

The estimated values $A I_{A S D}$ classified according to the categories in Table 6.

Comparison analysis of the drought and aridity indices

In the Table 7 illustrated the types of necessary input data, advantages and disadvantages for each of the drought and aridity indices adopted in this study.

Statistical analysis

In order to identify the method of estimation of dry and the results were subjected to analysis of variance and the averages compared by Tukey's statistical test (Mendes, 1999; Silva \& Silva, 2003), at a level of $5 \%$ probability, using the software Statistica ${ }^{\circledR}$.

The Tukey Test calculated based on the Significant Minimum Difference (DMS), that is, the minimum value for two treatments to be different through Equation 21:

$$
D M S=q_{(\alpha \%)} \sqrt{\frac{Q M R}{r}}
$$

where: $q$ is the amplitude tabled at a level of significance $(\alpha \%)$; QMR is the average square of the residue obtained by means of variance analysis (ANOVA); and $r$ is the number of repetitions of each treatment.

Whenever the absolute value of the difference between two means is equal to or greater than the significant minimum difference (DMS), the means considered statistically different at the established significance level.

The categorization of the letters in the Tukey test is made from the construction of a frame, where the means of the treatments are placed in increasing or decreasing order, and then the letter "a" is added in the first mean, letter "b" for the second treatment if different from the first treatment, and so on (Mendes, 1999). aridity index that best suited the region of the Brígida river basin, 


\section{Climate trend}

TREND software (Chiew et al., 2017) was used to analyse behavioural changes in the series of dry and aridity indices using the statistical tests of Mann-Kendall, Spearman's Rho, Linear Regression, Cumulative Deviation, Worsley likelihood, Rank Sum and Student's, with significance levels of $0.1 ; 0.05$ and 0.01 , where the mean period of 1961-1990 was compared with 1991-2016.

\section{RESULTS AND DISCUSSION}

\section{Climate variables}

In order to observe the differences in behaviour in some climatic variables, were analysed some data the normal climatological standard (1961 to 1990) and provisional normal (1991 to 2016), presented respectively in Table 8 and Table 9.

According to the data, there was an increase in normal climatological standard (1991-2016) when provisional normal (1961-1990) were compared in the parameters of average, minimum and maximum temperature of $3.8 \%, 4.2 \%$ and $2.5 \%$, respectively; while there was a reduction in precipitation and relative humidity of $-18.1 \%$ and $-3 \%$, simultaneously.

The above data corroborate the hypothesis of a trend change in the region of the Brígida river basin on a time scale, since the most recent data (provisional normal) are different when compared to the older data (normal climatological standard). This behaviour can directly interfere in the occurrence of extreme hydrologic events, such as drought, and favour the acceleration of aridity and desertification processes.

\section{Drought indices}

Rainfall Anomaly Index (RAI)

From the analysis of the RAI data (Table 10), it was found that categories R0, R1 and R2, which refer to the extremely wet, very wet and wet classes, respectively gathered represented in the period 1961-1990 about 39\% records. In the 1991-2016 interval there were about $33 \%$ records for the same classes, that is, there was a reduction of $-16.9 \%$ in the records of categories R0, R1 and R2 referring to values classified as wet period.

In addition, the categories R3 (dry), R4 (very dry) and R5 (extremely dry) gathered total around 61\% records in the period 1961-1990, while in the 1991-2016 interval, about 67\% were recorded data, indicating that there was an increase of $10.9 \%$ of the records classified as dry period.

The results suggest that the wet period ( $\mathrm{R} 0, \mathrm{R} 1$ and $\mathrm{R} 2$ together) for the 13 municipalities in the territory of the basin have reduced in recent years (1991-2016), which in the long term may cause several problems related to water resources, such as low availability of water for supply and increased susceptibility to desertification processes.

According to the analysis of the climatic trend, there is no distinction of the RAI values in the period of 1961-1990 when
Table 8. Climate variables of Cabrobó Station (82886), according normal climatological standard (1961-1990).

\begin{tabular}{cccccc}
\hline Month & $\begin{array}{c}\text { Rainfall } \\
(\mathbf{m m})\end{array}$ & $\begin{array}{c}\text { AVG } \\
\left({ }^{\circ} \mathbf{C}\right)\end{array}$ & $\begin{array}{c}\text { MIN } \\
\left({ }^{\circ} \mathbf{C}\right)\end{array}$ & $\begin{array}{c}\text { MAX } \\
\left({ }^{\circ} \mathbf{C}\right)\end{array}$ & UR (\%) \\
\hline Jan & 87.2 & 27.0 & 22.4 & 32.8 & 57 \\
Feb & 85.8 & 26.5 & 22.2 & 32.0 & 61 \\
Mar & 136.1 & 26.4 & 22.0 & 31.9 & 67 \\
Apr & 104.6 & 25.6 & 21.7 & 31.0 & 67 \\
May & 40.4 & 24.8 & 20.8 & 29.9 & 67 \\
Jun & 19.4 & 24.0 & 19.8 & 29.1 & 66 \\
Jul & 13.5 & 23.7 & 19.1 & 29.1 & 65 \\
Aug & 3.8 & 24.5 & 19.4 & 30.2 & 59 \\
Sep & 4.1 & 26.0 & 20.7 & 32.0 & 53 \\
Oct & 10.5 & 27.9 & 22.1 & 34.0 & 48 \\
Nov & 38.8 & 28.4 & 22.8 & 34.1 & 49 \\
Dec & 55.4 & 27.7 & 22.7 & 33.7 & 54 \\
Annual & $\mathbf{5 9 9 . 5}$ & $\mathbf{2 6}$ & $\mathbf{2 1 . 3}$ & $\mathbf{3 1 . 7}$ & $\mathbf{5 9 . 4}$ \\
\hline AVG & & &
\end{tabular}

$\mathrm{AVG}=$ average air temperature; $\mathrm{MIN}=$ minimum air temperature; MAX $=$ maximum air temperature; $\mathrm{UR}=$ relative humidity. Source: Instituto Nacional de Meteorologia (2009).

Table 9. Climate variables of Cabrobó Station (82886), according provisional normal (1991-2016).

\begin{tabular}{cccccc}
\hline Month & $\begin{array}{c}\text { Rainfall } \\
(\mathbf{m m})\end{array}$ & $\begin{array}{c}\text { AVG } \\
\left({ }^{\circ} \mathbf{C}\right)\end{array}$ & $\begin{array}{c}\text { MIN } \\
\left({ }^{\circ} \mathbf{C}\right)\end{array}$ & $\begin{array}{c}\text { MAX } \\
\left({ }^{\circ} \mathbf{C}\right)\end{array}$ & UR (\%) \\
\hline Jan & 85.7 & 28.0 & 23.2 & 33.6 & 56 \\
Feb & 77.4 & 27.7 & 23.1 & 33.3 & 60 \\
Mar & 110.7 & 27.5 & 23.1 & 32.9 & 64 \\
Apr & 67.6 & 27.1 & 22.8 & 32.5 & 64 \\
May & 32.4 & 26.1 & 22.0 & 31.4 & 65 \\
Jun & 8.5 & 25.0 & 20.9 & 30.3 & 65 \\
Jul & 11.5 & 24.3 & 19.9 & 29.7 & 63 \\
Aug & 5.3 & 24.9 & 19.9 & 30.6 & 58 \\
Sep & 2.3 & 26.7 & 21.0 & 32.6 & 51 \\
Oct & 10.7 & 28.3 & 22.5 & 34.3 & 47 \\
Nov & 28.3 & 29.1 & 23.6 & 34.8 & 46 \\
Dec & 50.9 & 28.9 & 23.8 & 34.6 & 50 \\
Annual & 491.2 & $\mathbf{2 7 . 0}$ & $\mathbf{2 2 . 2}$ & $\mathbf{3 2 . 5}$ & $\mathbf{5 7 . 6}$ \\
\hline AVG & & &
\end{tabular}

$\mathrm{AVG}=$ average air temperature; MIN = minimum air temperature; $\mathrm{MAX}=$ maximum air temperature; $\mathrm{UR}=$ relative humidity. Source: Instituto Nacional de Meteorologia (2017).

Table 10. RAI for the 38 pluviometric stations of the Brígida river basin in the period 1961 to 2016.

\begin{tabular}{|c|c|c|c|c|c|}
\hline \multirow{2}{*}{ Classes } & \multicolumn{2}{|c|}{$1961-1990$} & \multicolumn{2}{|c|}{ 1991-2016 } & \multirow{2}{*}{$\begin{array}{c}\text { Growth } \\
\text { Rate } \\
(\%)\end{array}$} \\
\hline & $\mathbf{N}^{\mathbf{o}}$ & $(\%)$ & $\mathbf{N}^{\mathbf{o}}$ & $(\%)$ & \\
\hline $\mathrm{R} 0$ & 725 & 5.30 & 230 & 1.94 & -63.4 \\
\hline R1 & 1288 & 9.42 & 707 & 5.96 & -36.7 \\
\hline $\mathrm{R} 2$ & 3358 & 24.55 & 2933 & 24.74 & +0.8 \\
\hline R3 & 3346 & 24.46 & 4490 & 37.87 & +54.8 \\
\hline $\mathrm{R} 4$ & 4952 & 36.20 & 3484 & 29.39 & -18.8 \\
\hline R5 & 10 & 0.07 & 12 & 0.10 & +38.5 \\
\hline
\end{tabular}

$\mathrm{R} 0$ = extremely wet; $\mathrm{R} 1$ = very wet; $\mathrm{R} 2$ = wet; $\mathrm{R} 3$ = dry; R4 = very dry; $\mathrm{R} 5=$ extremely dry. 
compared to the period of 1991-2016, for most pluviometric stations in the basin, considering that on average $77 \%$ of them presented results statistically Not Significant (NS), as presented in Table 11.

In general, the pluviometric stations that showed significant statistical difference in the value of RAI had higher data means in 1961-1990, greater than those from 1991-2016, suggesting that in this period there was a higher amount of precipitation, given that the higher values of RAI classified in the wet category.

The only pluviometric station that presented inverse behaviour for the RAI climatic trend analysis was station 739031, located in the municipality of Serrita/PE. This is probably due to some orographic effect in the basin, considering that it is located in higher altitude part.

Orography is an important factor active in the dynamics of the constituent attributes of the climate, in order to intensify or reduce the total rainfall, according to the windward or leeward position (Cândido \& Nunes, 2008).

According to Ganem (2017), the highest regions such as Chapada do Araripe, with an altitude of more than 900 meters, where the Brígida river basin is situated, receive orographic rains, while depressions such as Depressure Sertaneja with altitudes of less than 500 meters form rain shadows.

Several authors, such as Conti (2005), Fechine \& Galvíncio (2014) and Dantas et al. (2018) observed the occurrence of the orographic effect in Chapada do Araripe and the Brígida river basin.

Felix (2015), when studying the Rain Anomaly Index (RAI) to identify temporal rainfall patterns in the Espinharas/PB river basin, located in the Northeast semi-arid, with characteristics similar to the Brígida river basin, found that the total rainfall over the years decreased significantly.

Gross \& Cassol (2015) found that the frequency of the negative Rainfall Anomaly Index (RAI) was higher in the Southwest sector of the State of Rio Grande do Sul in the last decade of the analysis period from 1991 to 2012. That is, there was a reduction in wet periods and increased records in the dry categories, similarly to that occurred in the Brígida river basin.

Eshetu et al. (2016) identified the occurrence of extreme negative anomalies in the annual rainfall in $42 \%$ of the years analysed, from 1979 to 2011 at the Setema station in Southwestern Ethiopia, which has characteristics similar to the semi-arid in northeastern Brazil, where the study area of this article is located. Allied to this, these authors also found that there is a tendency to decrease precipitation, that is, the records indicative of dry category are more frequent than the wet periods, also to that occurred in the municipalities of the Brígida river basin.

Costa \& Rodrigues (2017), when analysing the space-temporal variation in the Salgado River basin in Ceará, through the Rain Anomaly Index (RAI), found that the historical series from 1974 to 2015 presented drier than rainy years. That is, these authors found results similar to those observed in the Brígida river basin in the period 1961-2016, where a higher number of records of dry period classes were detected.

Lins et al. (2017), using RAI, were able to identify the occurrence of negative anomalies in 1989 and 1998 in the municipality of Serra Talhada in Pernambuco.

The above results indicate that the situation with the highest occurrence of dry periods is not isolated in a single region, of a
Table 11. RAI climate trend analysis in TREND software for the periods 1961 to 1990 and 1991 to 2016 for the 38 rainfall stations located in the Brígida river basin.

\begin{tabular}{lcccc}
\hline \multicolumn{1}{c}{ Tests } & NS & $\boldsymbol{\alpha}=\mathbf{0 . 1}$ & $\boldsymbol{\alpha}=\mathbf{0 . 0 5}$ & $\boldsymbol{\alpha}=\mathbf{0 . 0 1}$ \\
\hline Mann-kendall & $87 \%$ & $3 \%$ & $11 \%$ & $0 \%$ \\
Spearman's Rho & $87 \%$ & $0 \%$ & $11 \%$ & $3 \%$ \\
Linear regression & $71 \%$ & $11 \%$ & $13 \%$ & $5 \%$ \\
Cumulative deviation & $71 \%$ & $13 \%$ & $13 \%$ & $3 \%$ \\
Worsley likelihood & $79 \%$ & $8 \%$ & $8 \%$ & $5 \%$ \\
Rank Sum & $76 \%$ & $11 \%$ & $8 \%$ & $5 \%$ \\
Student's $^{1}$ & $71 \%$ & $11 \%$ & $13 \%$ & $5 \%$ \\
\hline
\end{tabular}

${ }^{1}$ All pluviometric stations with a significant difference obtained an average of 1961-1990 greater than 1991-2016, the only exception being station 739031 . NS $=$ Not Significant for $\alpha=0.05$ and 0.01 .

Table 12. SPI for the 38 pluviometric stations of the Brígida river basin in the period 1961 to 2016.

\begin{tabular}{|c|c|c|c|c|c|}
\hline \multirow{2}{*}{ Classes } & \multicolumn{2}{|c|}{$1961-1990$} & \multicolumn{2}{|c|}{ 1991-2016 } & \multirow{2}{*}{$\begin{array}{l}\text { Growth } \\
\text { Rate (\%) }\end{array}$} \\
\hline & $\mathbf{N}^{\mathbf{o}}$ & $(\%)$ & $\mathbf{N}^{\mathbf{o}}$ & $(\%)$ & \\
\hline So & 303 & 2.55 & 0 & 0.00 & -100.0 \\
\hline S1 & 835 & 7.02 & 26 & 0.22 & -96.9 \\
\hline S2 & 1853 & 15.58 & 125 & 1.05 & -93.2 \\
\hline S3 & 8148 & 68.51 & 8746 & 73.77 & +7.7 \\
\hline S4 & 456 & 3.83 & 900 & 7.59 & +98.0 \\
\hline S5 & 217 & 1.82 & 1025 & 8.65 & +373.9 \\
\hline S6 & 82 & 0.69 & 1034 & 8.72 & +1165.0 \\
\hline
\end{tabular}

S0 = extremely wet; S1 = very wet; S2 = moderately wet; S3 = near normal; $\mathrm{S} 4=$ moderately dry; S5 = severely dry; S6 = extremely dry.

given country, and that it needs to be constantly monitored by the bodies of water management, especially in the semi-arid region. This premise is because in recent decades, the data have shown that droughts are more frequent, and this can directly interfere with water availability, which in turn may generate conflicts through water use.

In addition, all the results presented suggest that the use of the Rain Anomaly Index (RAI) for the identification of wet and dry periods, as well as evaluation of the trend of decreased precipitation is extremely reliable. Besides, RAI can become a crucial tool not only in monitoring water availability, but also in the evolution of susceptibility to the desertification process, and the influence of events related to climate change, especially in basins hydrographic sites located in semi-arid regions.

\section{Standardized Precipitation Index (SPI)}

The results of the SPI (Table 12) indicate that the categories referring to wet periods, such as S0 (extremely wet), S1 (very wet), S2 (moderately wet) showed a reduction in the number of records in the interval of 1991-2016 (25.15\%) when compared to 1961-1990 (1.27\%). These data suggest a decrease in the number of values classified as wet in the last years of the analysed series around $-94.9 \%$.

The S3 (near normal), S4 (moderately dry), S5 (severely dry) and S6 (extremely dry) classes gathered went from $74.85 \%$ in the range of $1961-1990$ to $98.73 \%$ in $1991-2016$, suggesting an intensification of dry periods from about $31.9 \%$. 
Table 13. SPI climate trend analysis in TREND software in the period 1961 to 1990 and 1991 to 2016 for the 38 rainfall stations located in the Brígida river basin.

\begin{tabular}{lcccc}
\hline \multicolumn{1}{c}{ Tests } & NS & $\boldsymbol{\alpha}=\mathbf{0 . 1}$ & $\boldsymbol{\alpha}=\mathbf{0 . 0 5}$ & $\boldsymbol{\alpha}=\mathbf{0 . 0 1}$ \\
\hline Mann-kendall & $21 \%$ & $8 \%$ & $13 \%$ & $58 \%$ \\
Spearman's Rho & $21 \%$ & $11 \%$ & $16 \%$ & $53 \%$ \\
Linear regression & $16 \%$ & $3 \%$ & $13 \%$ & $68 \%$ \\
Cumulative deviation & $8 \%$ & $13 \%$ & $16 \%$ & $63 \%$ \\
Worsley likelihood & $0 \%$ & $0 \%$ & $0 \%$ & $100 \%$ \\
Rank Sum & $16 \%$ & $5 \%$ & $26 \%$ & $53 \%$ \\
Student's $^{1}$ & $5 \%$ & $18 \%$ & $18 \%$ & $58 \%$ \\
\hline
\end{tabular}

${ }^{1}$ All pluviometric stations with a significant difference obtained an average of 1961-1990 greater than 1991-2016. NS $=$ Not Significant for $\alpha=0.05$ and 0.01 .

This behaviour was also observed in the analysis of the climatic trend (Table 13). There was a statistically significant difference in the mean dry period of 1961-1990 when compared to 1991-2016 in most of the pluviometric stations in the basin at the level of 0.01 significance level.

The analysis of the climatic trend of the SPI indicates that the highest values, that is, those that corresponded to the classification of humid periods, occurred in greater quantity between 1961-1990 than in the years 1991 to 2016, implying that there was a quantitative reduction in the rain in the region of the Brígida river basin.

Similar studies such as Guenang \& Kamga (2014) concluded that in the 55-year temporal series of SPI, severe and extreme drought episodes are identified in many seasons during the analysed period, and that moderate and severe drought occurrences are on short and interannual time scales for long periods in Cameroon's semi-arid region. These results were similar to those observed in the present study in the Brígida river basin, where it was found that the moderately dry (S4), severely dry (S5) and extremely dry (S6) categories intensified in the last years of the analysed series.

Sampaio \& Pinto (2018), when using the SPI to determine the severity of drought in the region, found that the droughts in the years 2012 to 2013 and 2016 to 2017 were extreme events that collaborated to reduce water availability of the Serra Azul reservoir, located in the Pernambuco state in Brazilian northeast. The results obtained by these authors were similar to those of the Brígida river basin, where it was also found that dry periods are intensifying, which can bring problems of water availability in the region, especially with regard to the level of accumulation of reservoirs used for human supply.

Faro et al. (2019) estimated the SPI to evaluate water stress in the Cantareira System, one of the main water producing systems in the Metropolitan Region of São Paulo (RMSP) in the Brazil, from 1983 to 2018. These authors verified that from the year 2000, despite an attenuated period between 2009 and 2011, the trend of growth of system deficits began to occur more intensely, with a greater gradient, considering both the volume and magnitude of the duration of the drought event. That is, these results are consistent with those observed in the Brígida river basin, in which the increase in the magnitude of droughts was identified in the 1991-2016 interval when compared to the period 1961-1990.

Pramudya et al. (2019), from the results of the SPI concluded that most of Indonesia had severe and extreme droughts in the period 1991-2006, and that Borneo Island and West Papua are the islands that stopped the most extreme drought during dry seasons analysed throughout the historical series. Results similar to those obtained by these authors were identified in the Brígida river basin, where the occurrence of moderate, severe and extreme drought intensification in the most recent years of the studied series was observed.

Koudahe et al. (2017), using the SPI on the 12-month time scale, observed that there is an increasing trend of dry periods, from 1970 to 2014, in southern Togo, which is detrimental to dry land agriculture practiced by about $90 \%$ of farmers in the region. This increasing trend of dry periods was also observed in the present study in the Brígida river basin.

Braga et al. (2015) found that the results of the SPI analysis, in the temporal scales of 12,18, 24 and 36 months, in the Piranhas-Açu river basin in Brazil. The results indicated that droughts occurred between the years 1980 and 1983, 1993, 1998, 1999, and 2012 to 2014 were the ones acting the most severe categories, much of the basin. In addition, the same authors concluded that SPI could be a good tool for managing water resources.

All the above results indicate that the intensification of the categories of droughts is not an isolated condition in the Brígida river basin, but that also occurs in other semi-arid regions of the world, which suggests the increase in the occurrence of hydrological events extremes such as droughts.

These phenomena directly interfere with water availability, and therefore need to be monitored by the management bodies to facilitate the implementation of measures that manage water resources, especially in periods of severe and extreme droughts.

In addition, the repeated occurrence of droughts of greater intensity can accelerate the process of desertification, which in the long term may make land use impossible for agricultural crops, interfering in subsistence agriculture and consequently in the economy local.

In this sense, one of the tools that can be used is the SPI, which indicates the severity of droughts and can be easily employed, since it only uses precipitation as input data, becoming an advantage in the management of water resources.

\section{Palmer Drought Severity Index (PDSI)}

According to the results of PDSI (Table 14), the classes P1 (extremely wet), P2 (very wet), P3 (moderately wet), P4 (slightly wet), P5 (incipient wet spell) and P6 (near normal) represented about $49.74 \%$ records in the period 1961-1990. In addition, these categories in the 1991-2016 interval decreased their quantitative to $30.79 \%$, suggesting that there was a reduction in values categorized as humid, equivalent to $-38.1 \%$.

Allied to this, categories P7 - incipient drought, P8 - mild drought, P9 - moderate drought, P10 - severe drought and P11 - extreme drought joints contemplate $50.26 \%$ in the period 1961-1990, while in the range of 1991-2016 these data increased to $69.21 \%$, indicating that there was a drought record growth corresponding to $37.7 \%$.

The behaviour of decreasing wet data and growth of drought records in the range of 1991-2016 when compared to the period 1961-1990 also verified in the 13 municipalities that are 
Table 14. PDSI for the 38 pluviometric stations of the Brígida river basin in the period 1961 to 2016.

\begin{tabular}{|c|c|c|c|c|c|}
\hline \multirow{2}{*}{ Classes } & \multicolumn{2}{|c|}{$1961-1990$} & \multicolumn{2}{|c|}{ 1991-2016 } & \multirow{2}{*}{$\begin{array}{l}\text { Growth } \\
\text { Rate }(\%)\end{array}$} \\
\hline & $\mathbf{N}^{\mathbf{o}}$ & $(\%)$ & $\mathrm{N}^{\mathbf{o}}$ & $(\%)$ & \\
\hline P1 & 6475 & 47.33 & 3315 & 27.96 & -40.9 \\
\hline P2 & 27 & 0.20 & 17 & 0.14 & -27.4 \\
\hline P3 & 28 & 0.20 & 26 & 0.22 & +7.1 \\
\hline P4 & 20 & 0.15 & 23 & 0.19 & +32.7 \\
\hline P5 & 9 & 0.07 & 18 & 0.15 & +130.8 \\
\hline P6 & 246 & 1.80 & 251 & 2.12 & +17.7 \\
\hline P7 & 22 & 0.16 & 22 & 0.19 & +15.4 \\
\hline P8 & 42 & 0.31 & 62 & 0.52 & +70.3 \\
\hline P9 & 64 & 0.47 & 56 & 0.47 & +1.0 \\
\hline P10 & 68 & 0.50 & 71 & 0.60 & +20.5 \\
\hline P11 & 6679 & 48.82 & 7995 & 67.43 & +38.1 \\
\hline
\end{tabular}

P1 = extremely wet; P2 = very wet; P3 = moderately wet; P4 = slightly wet; P5 = incipient wet spell; P6 = near normal; P7 = incipient drought; P8 = mild drought; P9 = moderate drought; P10 = severe drought; P11 = extreme drought.

Table 15. PDSI climate trend analysis in TREND software in the period 1961 to 1990 and 1991 to 2016 for the 38 rainfall stations located in the Brígida river basin.

\begin{tabular}{lcccc}
\hline \multicolumn{1}{c}{ Tests } & NS & $\boldsymbol{\alpha}=\mathbf{0 . 1}$ & $\boldsymbol{\alpha}=\mathbf{0 . 0 5}$ & $\boldsymbol{\alpha}=\mathbf{0 . 0 1}$ \\
\hline Mann-kendall & $18 \%$ & $13 \%$ & $39 \%$ & $29 \%$ \\
Spearman's Rho & $21 \%$ & $11 \%$ & $42 \%$ & $26 \%$ \\
Linear regression & $13 \%$ & $5 \%$ & $34 \%$ & $47 \%$ \\
Cumulative deviation & $24 \%$ & $8 \%$ & $37 \%$ & $32 \%$ \\
Worsley likelihood & $3 \%$ & $5 \%$ & $24 \%$ & $68 \%$ \\
Rank Sum & $13 \%$ & $21 \%$ & $29 \%$ & $37 \%$ \\
Student's $^{1}$ & $3 \%$ & $8 \%$ & $34 \%$ & $55 \%$ \\
\hline
\end{tabular}

${ }^{1}$ All pluviometric stations with a significant difference obtained an average of 1961-1990 greater than 1991-2016. NS $=$ Not Significant for $\alpha=0.05$ and 0.01 .

inserted in the territory of the Brígida river basin, suggesting that it is not an isolated condition, from a geographical point of view.

In the analysis of climatic trend (Table 15), the pluviometric stations that had a significant statistical difference, presented a mean PDSI of 1961-1990 higher than 1991-2016, indicating a decrease in the wet period in the territory of the Brígida river basin.

Similar results were obtained by Rodrigues et al. (2018), through the PDSI, led to the conclusion that drought remains a recurrent phenomenon in the Pajeú river basin, located in Pernambuco, becoming more severe the last 30 years. The alteration of the rainfall associated with increased air temperature may explain the occurrence of this more severe drought in the basin.

In the Brígida river basin, as well as in Rodrigues et al. (2018) it was observed that droughts are becoming more intense in recent years (1991-2016) and that wet periods have been decreasing over the period studied, when compared to older years (1961-1990) of the historical series analysed.

Silveira et al. (2017) when estimating the PDSI index for the city of Pelotas in Rio Grande do Sul, for the period from 1980 to 2013 identified some severe and extreme drought values, and it was observed that most periods correspond to moderate drought, and some peaks of especially in the periods from 2004 to 2010. Similarly, the Brígida river basin also verified the intensification of droughts in the temporal scale analysed.
Rossato et al. (2017), through the PDSI, concluded that the Northeast has more intense drought levels, when compared to the other regions of Brazil, in the period from 2000 to 2015. In addition, climate projection analysis using the Coupled Model Intercomparison Project Phase 5 (CMIP5) presented for the future, through simulation results for the period 2071-2100, risks of severe droughts in the semi-arid Northeast, with reductions rainfall of up to $40 \%$ and increased consecutive dry days.

These data are consistent with those observed in the Brígida river basin, where wet periods associated with the intensification of droughts in recent years of the historical series studied were detected. This behaviour is extremely worrying, especially in the medium and long term, as it can increase the effect of processes related to climate change, such as desertification, which affects water availability and agricultural productivity of semi-arid region.

In this context, the use of PDSI becomes a crucial tool for monitoring extreme hydrological events, such as dryness and droughts, because it verifies whether they are intensifying on the time scale. In addition, PDSI index can be used to monitor desertification susceptibility, because one of its input data is the elements of the water balance, which involves recharge, surface runoff, soil moisture, factors that are extremely influenced by climate factors.

\section{Aridity indices}

Martonne's Aridity (MIA)

Regarding MIA, it was found that categories M0 (humidity above normal), M1 (wet) and M2 (humidity below normal) had about $30.16 \%$ records in the period 1961-1990. In the 1991-2016 interval, these same categories reduced to $25.50 \%$, which corresponds to a decrease of $-15.5 \%$ (Table 16 ).

The estimated MIA data also showed that the M3 (semi-arid), M4 (arid) and M5 (extremely arid) classes obtained 69.84\% records in the period 1961-1990, while in the 1991-2016 interval they rose to $74.50 \%$, representing a growth of $6.7 \%$ (Table 16 ).

The results suggest that in the Brígida river basin there was a reduction in records classified as wet (M0, M1 and M2) and growth of values categorized as arid (M3, M4 and M5), in the period 1991-2016 when compared to the interval of 1961-1990.

This behaviour of elevation of aridity was verified in all 13 municipalities inserted in the territory of the Brígida river basin, suggesting that this is not an isolated condition, and that in the medium and long term can favour the desertification of soils, bringing socio-economic damage to the local population.

The results of the MIA climate trend analysis (Table 17) show that there is a statistically significant difference in some pluviometric stations in the basin, suggesting that data from the period 1961-1990 are less in terms of aridity than those of 1991-2016, which implies saying that aridity is evolved in the region, and can increase susceptibility to desertification.

These results are coherent since the basin is fully located in the semi-arid region of Brazil, with low rainfall indices, high evaporation and irregular rainfall distribution. 
Table 16. MIA for the 38 pluviometric stations of the Brígida river basin in the period 1961 to 2016.

\begin{tabular}{cccccccc}
\hline \multirow{2}{*}{ Classes } & \multicolumn{2}{c}{$\mathbf{1 9 6 1 - 1 9 9 0}$} & & \multicolumn{2}{c}{$\mathbf{1 9 9 1 - 2 0 1 6}$} & Growth \\
\cline { 2 - 3 } & $\mathbf{N}^{\mathbf{o}}$ & $\mathbf{( \% )}$ & & $\mathbf{N}^{\mathbf{o}}$ & $\mathbf{( \% )}$ & Rate (\%) \\
\hline M0 & 916 & 6.70 & & 354 & 2.99 & -55.4 \\
M1 & 1918 & 14.02 & & 1588 & 13.39 & -4.5 \\
M2 & 1292 & 9.44 & & 1081 & 9.12 & -3.5 \\
M3 & 795 & 5.81 & & 706 & 5.95 & +2.5 \\
M4 & 2859 & 20.90 & & 2478 & 20.90 & +0.01 \\
M5 & 5900 & 43.13 & & 5649 & 47.65 & +10.5 \\
\hline
\end{tabular}

M0 = humidity above normal; M1 = wet; M2 = humidity below normal; M3 = semi-arid; M4 = arid; M5 = extremely arid.

Table 17. MIA climate trend analysis in TREND software in the period 1961 to 1990 and 1991 to 2016 for the 38 rainfall stations located in the Brígida river basin.

\begin{tabular}{lcccc}
\hline \multicolumn{1}{c}{ Tests } & NS & $\boldsymbol{\alpha}=\mathbf{0 . 1}$ & $\boldsymbol{\alpha}=\mathbf{0 . 0 5}$ & $\boldsymbol{\alpha}=\mathbf{0 . 0 1}$ \\
\hline Mann-kendall & $42 \%$ & $24 \%$ & $21 \%$ & $13 \%$ \\
Spearman's Rho & $39 \%$ & $29 \%$ & $24 \%$ & $8 \%$ \\
Linear regression & $32 \%$ & $21 \%$ & $34 \%$ & $13 \%$ \\
Cumulative deviation & $55 \%$ & $16 \%$ & $21 \%$ & $8 \%$ \\
Worsley likelihood & $34 \%$ & $47 \%$ & $11 \%$ & $8 \%$ \\
Rank Sum & $53 \%$ & $29 \%$ & $13 \%$ & $5 \%$ \\
Student's & $26 \%$ & $26 \%$ & $39 \%$ & $8 \%$ \\
\hline
\end{tabular}

${ }^{1}$ All pluviometric stations with a significant difference obtained an average in 1961-1990 greater than 1991-2016. NS = Not Significant for $\alpha=0.05$ and 0.01 .

This behaviour also observed by Lopes \& Leal (2015), who has detected an increase in the Martonne Aridity Index (MIA) for the period 1961 to 2015, in Northeastern Brazil, in the municipalities of Lençóis, Bom Jesus da Lapa, Cabrobó and Garanhuns, making them most susceptible to desertification.

Chowdhury (2018) using the Martonne Aridity Index (MIA) in Bangladesh, in two distinct periods, from 1991 to 2000 and 2001-2010, as well as the present study in the Brígida river basin, also found that the severity and distribution of aridity has a standard over the past few years.

Moral et al. (2017), when using the Martonne Aridity Index (MIA), from 1951 to 2010, there was an increase in aridity, with a significant statistical difference being detected from the end of the 1970s, compared to the other years analysed in the Southwest of Spain.

Dabaghi \& Manjari (2017), when using the Martonne Aridity Index (MIA), in the Razan-Qhahavand basin, located in Iran, found that aridity on the plain becomes growing over the years (1983-2013), probably due to global warming, which collaborates with the process of desertification, becoming a danger to people living in this area. These authors obtained results similar to those observed in the Brígida river basin where there was an intensification of aridity throughout the historical series analysed, indicating an increase in susceptibility to desertification in the region.

Muhire \& Ahmed (2016), through the Martonne Aridity Index (MIA) found that there was an increase in aridity in the highland region and western Rwanda in the period 1961-1992, and that these areas most affected by droughts, reduced availability and consequently loss of agricultural production. A situation similar to that observed in the Brígida river basin, where an increase in aridity and decreased wet periods obtained, which may consequently affect local water availability.

The research presented above shows how semi-arid regions in various parts of the world are suffering an increase in aridity in recent years and consequently a reduction in wet periods that directly affect water availability. Combined with this, the evolution of aridity makes territories more susceptible to the desertification process, which can be accelerated due to local and/or global climate change.

In this sense, the use of indices for measuring the evolution of aridity, like MIA, are crucial because they can provide decision-making elements by the supervisory bodies. In addition to allowing desertification-related projects to be implemented in a timely manner so that this process does not definitively install itself in the territory of the hydrographic basin, especially those located in semi-arid regions, such as the Brígida river basin.

Mainly because according to research developed by Fundação Oswaldo Cruz (2017) using SisVuClima software, the state of Pernambuco may have drier and warmer days from 2041. According to the analyses made, the Sertão of Pernambuco may have an increase of up to $3.7^{\circ} \mathrm{C}$ in temperature, as is the case of the municipality of Araripina. In addition, the São Francisco river region, where the Brígida river basin is a tributary, would be the most affected by the reduction in precipitation, reaching a volume of $-39 \%$ in the municipality of Petrolândia, for example. Moreover, since precipitation and temperature factors directly influence aridity, it could intensify even further in the basin region.

\section{Thornthwaite's Aridity Index (AI)}

AI data (Table 18) indicate that the categories Little or no water deficiency (A0) and Moderate hydric deficiency (A1) together obtained 68.25\% records, in the period 1961-1990, while in the years $1991-2016$, these classes went to $73.90 \%$, that is, they had an increase of $15.2 \%$. Class A2 (Great water deficiency) obtained $31.75 \%$ and $26.10 \%$ records respectively for the years $1961-1990$ and 1991-2016, representing that there was a drop of $-17.8 \%$ in this category.

Although class A2 (great water deficiency) has decreased in recent years (1991-2016), the situation still needs continuous monitoring of climate variables, extreme events and the implementation of measures related to the management of water resources, in order to avoid increasing susceptibility to desertification in the Brígida river basin.

This hypothesis is based on the results of the AI climate trend analysis (Table 19) indicated that, on average, approximately $28 \%$ of the rainfall stations presented statistical differences at the level of 0.1 of significance, inferring that the mean of the period of 1961-1990 was higher than 1991-2016.

This indicates that in the period 1961-1990 aridity was less intense, when compared to the years 1991-2016, and that in recent years aridity has been growing in the area of study. This behaviour is probably due to the reduction of precipitation and elevation of evapotranspiration in the region of the Brígida river basin.

This premise based on the results of Sá et al. (2010), which, through simulation, verified in the optimistic scenario, in 2030, a significant increase in the São Francisco river basin for potential 
Table 18. AI for the 38 pluviometric stations of the Brígida river basin in the period 1961 to 2016.

\begin{tabular}{|c|c|c|c|c|c|}
\hline \multirow{2}{*}{ Classes } & \multicolumn{2}{|c|}{ 1961-1990 } & \multicolumn{2}{|c|}{ 1991-2016 } & \multirow{2}{*}{$\begin{array}{l}\text { Growth } \\
\text { Rate (\%) }\end{array}$} \\
\hline & $\mathbf{N}^{\mathbf{o}}$ & $(\%)$ & $\mathbf{N}^{\mathbf{o}}$ & $(\%)$ & \\
\hline A0 & 7295 & 53.33 & 6880 & 58.03 & +8.8 \\
\hline A1 & 2042 & 14.93 & 1882 & 15.87 & +6.3 \\
\hline A2 & 4343 & 31.75 & 3094 & 26.10 & -17.8 \\
\hline
\end{tabular}

A0 = little or no water deficiency; A1 = moderate hydric deficiency; A2 = great water deficiency.

Table 19. AI climate trend analysis in TREND software in the period 1961 to 1990 and 1991 to 2016 for the 38 rainfall stations located in the Brígida river basin.

\begin{tabular}{lcccc}
\hline \multicolumn{1}{c}{ Tests } & NS & $\boldsymbol{\alpha}=\mathbf{0 . 1}$ & $\boldsymbol{\alpha}=\mathbf{0 . 0 5}$ & $\boldsymbol{\alpha}=\mathbf{0 . 0 1}$ \\
\hline Mann-kendall & $47 \%$ & $29 \%$ & $21 \%$ & $3 \%$ \\
Spearman's Rho & $47 \%$ & $29 \%$ & $18 \%$ & $5 \%$ \\
Linear regression & $39 \%$ & $29 \%$ & $26 \%$ & $5 \%$ \\
Cumulative deviation & $58 \%$ & $18 \%$ & $16 \%$ & $8 \%$ \\
Worsley likelihood & $61 \%$ & $32 \%$ & $5 \%$ & $3 \%$ \\
Rank Sum & $50 \%$ & $24 \%$ & $21 \%$ & $5 \%$ \\
Student's & $16 \%$ & $34 \%$ & $45 \%$ & $5 \%$
\end{tabular}

${ }^{1}$ All pluviometric stations with a significant difference obtained an average of 1961-1990 greater than 1991-2016. NS $=$ Not Significant for $\alpha=0.05$ and 0.01 .

evapotranspiration, which will be between 1,490 and 1,590 mm/year. This same simulation, in the pessimistic scenario will leave evapotranspiration with 1,590 to $1,690 \mathrm{~mm} /$ year, in 2030 . In addition, the simulations showed an increase for the years 2050 and 2070 with the same growth trend of evapotranspiration.

Allied to this, Fundação Oswaldo Cruz (2017) found that in the State of Pernambuco, the Region of the São Francisco river basin would be the most affected by the reduction in precipitation, and as the Brígida river basin is tributary in the Sub-Middle San Francisco will be strongly influenced.

Similar results were found by Souza et al. (2010), in which the aridity index (AI) showed a statistically significant increase nucleus, at the level of $5 \%$ probability, in the Araripina micro region, with an annual maximum increase of around $1.65 \%$ in the municipality of Exú, in the state of Pernambuco.

Santos et al. (2018), analysed data from the Annual Average Precipitation (P), Potential Evapotranspiration (ETP) and Aridity Index (AI) in the Piracuruca River basin (PI/CE). These authors concluded that the highest levels of AI were concentrated in the areas, which registered the smallest precipitation totals and the highest values of ETP. Similarly, it happens in the Brígida river basin, where it was detected that there is a reduction in precipitation and an increase in aridity in the period 1991-2016 through climate trend analysis.

Jesus et al. (2019), when applying the Thornthwaite Aridity Index (AI) to the semi-arid of the state of Sergipe, verified the highest values of aridity (0.09) in Canindé de São Francisco and Poço Redondo, and, consequently, presenting higher risk of desertification in these municipalities. That is, these authors verified a situation analogous to that occurred in the Brígida river basin, where there has been growth in categories A0 and A1 over the years, which can consequently promote desertification.
Ahmed et al. (2019) when calculating the Thornthwaite Aridity Index (AI) identified a growing trend in the period 1901-2016 in aridity values in Southwestern Pakistan, and observed significant statistical changes in precipitation and aridity between 1971 and 1980 compared to other years, as well as in the Brígida River in the period 1991-2016 in climate trend analysis.

Gao et al. (2015) based on the results of the Thornthwaite Aridity Index (AI), found that half of the stations located in the Eastern Tibetan Plateau showed precipitation reduction, that is, they are becoming more arid, although they are not statistically, in the last three decades. In addition, according to these authors, the increase in aridity values is statistically correlated with patterns of precipitation change, sun duration and daytime temperature range.

The above research suggests that in general, there is a decrease in precipitation and an increase in aridity in recent years, in various parts of the world, not only in the semi-arid northeast of Brazil, and in that these changes may be related to the effects of climate change.

These results are extremely worrying, because with the increase of AI, there is an increase in water deficiency, which requires investments for sanitation infrastructure regarding the conscious use of water, reuse and use, in order to minimize deficits in human supply.

Therefore, the monitoring of aridity, through indices, such as AI becomes an effective tool that can be easily applied in several regions of the planet reliably, especially for monitoring susceptibility to desertification, which brings immense damage to local agricultural productivity.

\section{Aridity Index of Areas Susceptible to Desertification $\left(\mathrm{AI}_{\mathrm{ASD}}\right)$}

The values of $\mathrm{AI}_{\mathrm{ASD}}$ (Table 20) demonstrated that the zone Dry subhumid (AI4) and Humid Subhumid (AI5) holds about $21.88 \%$ records, in the period of 1961-1990. In the 1991-2016 interval, these records decreased to $18.09 \%$. These changes in records in the period 1991-2016 when compared to the 1961-1990 interval indicate there was a decrease of $-17.3 \%$ in the wet zones in the Brígida river basin.

Allied to this, category AI1 achieved an 8.1\% increase in records when compared to data from 1991-2016 to 1961-1990, which is extremely worrying, because this category has most of the $\mathrm{AI}_{\mathrm{ASD}}$ records of the basin, and becoming increasing in the in recent years of the historical series, suggests an evolution of the region to susceptibility to desertification.

This behaviour also observed in the climatic trend analysis (Table 21), where it was found that on average, about $32 \%$ of the pluviometric stations in the basin showed statistical difference at the level of 0.01 of significance in the Student's Test, indicating that the $\mathrm{AI}_{\mathrm{ASD}}$ values in the period 1961-1990 are more humid when compared to those of 1991-2016. This implies saying that susceptibility to desertification is intensifying in the last period-analysed (1991-2016) in the Brígida river basin, and that precipitation reduction associated with increased evapotranspiration is probably due.

This reasoning can be ratified by the results obtained by Fundação Oswaldo Cruz (2017), where it was observed that in 
Table 20. $\mathrm{AI}_{\mathrm{ASD}}$ for the 38 pluviometric stations of the Brígida river basin in the period 1961 to 2016.

\begin{tabular}{|c|c|c|c|c|c|}
\hline \multirow{2}{*}{ Classes } & \multicolumn{2}{|c|}{ 1961-1990 } & \multicolumn{2}{|c|}{ 1991-2016 } & \multirow{2}{*}{$\begin{array}{l}\text { Growth } \\
\text { Rate }(\%)\end{array}$} \\
\hline & $\mathbf{N}^{\mathbf{o}}$ & $(\%)$ & $\mathbf{N}^{\mathbf{0}}$ & $(\%)$ & \\
\hline AI1 & 4841 & 35.39 & 4534 & 38.24 & +8.1 \\
\hline AI2 & 3028 & 22.13 & 2876 & 24.26 & +9.6 \\
\hline $\mathrm{AI} 3$ & 2818 & 20.60 & 2301 & 19.41 & -5.8 \\
\hline AI4 & 775 & 5.67 & 718 & 6.06 & +6.9 \\
\hline AI5 & 2218 & 16.21 & 1427 & 12.04 & -25.8 \\
\hline
\end{tabular}

AI1 = hyper-arid zone; AI2 = arid zone; AI3 = semi-arid zone; AI4 = dry subhumid zone; AI5 = humid subhumid zone.

Table 21. $\mathrm{AI}_{\mathrm{ASD}}$ climate trend analysis in TREND software in the period 1961 to 1990 and 1991 to 2016 for the 38 rainfall stations located in the Brígida river basin.

\begin{tabular}{lcccc}
\hline \multicolumn{1}{c}{ Tests } & NS & $\boldsymbol{\alpha}=\mathbf{0 . 1}$ & $\boldsymbol{\alpha}=\mathbf{0 . 0 5}$ & $\boldsymbol{\alpha}=\mathbf{0 . 0 1}$ \\
\hline Mann-kendall & $47 \%$ & $32 \%$ & $18 \%$ & $3 \%$ \\
Spearman's Rho & $50 \%$ & $26 \%$ & $18 \%$ & $5 \%$ \\
Linear regression & $39 \%$ & $26 \%$ & $29 \%$ & $5 \%$ \\
Cumulative deviation & $58 \%$ & $18 \%$ & $16 \%$ & $8 \%$ \\
Worsley likelihood & $61 \%$ & $32 \%$ & $5 \%$ & $3 \%$ \\
Rank Sum & $47 \%$ & $21 \%$ & $26 \%$ & $5 \%$ \\
Student's $^{1}$ & $21 \%$ & $11 \%$ & $37 \%$ & $32 \%$ \\
\hline
\end{tabular}

${ }^{1}$ All pluviometric stations with a significant difference showed an average of 1961-1990 greater than 1991-2016. NS $=$ Not Significant for $\alpha=0.05$ and 0.01 .

the State of Pernambuco, the region of the São Francisco river basin will be the most affected by the reduction of precipitation, as well as, will have an increase in the evapotranspiration, according to Sá et al. (2010).

The evolution of aridity and susceptibility to desertification in the Northeast, but specifically in the Basin of the Brígida river basin can be justified by several factors, such as man-led activities, such as livestock, irrigation, deforestation, and mining and in addition to the land ownership system and overpopulation, according to Centro de Gestão e Estudos Estratégicos (2016).

This premise is quite consistent with the Brígida river basin, since in its territory is located the Gesseiro pole of the Araripe, which has as its main activity, the mineral exploitation of gypsum. This activity developed for years in the basin without proper forest management, recovery projects of degraded areas, associated with the environmental oversight deficit, contributed considerably to the environmental degradation of the region, which according to Araújo (2004) and Granja et al. (2017) can make desertification quickly become something concrete.

Lucena et al. (2018), when studying aridity in the state of Rio Grande do Norte, found that the municipality of Caicó is highly susceptible to the desertification process, since the average value of the aridity index was 0.41, in the period of 1996-2013. These authors observed results similar to those found in the Brígida river basin in the period 1991-2016, where an increase in aridity and susceptibility to the desertification process was observed.

The results of the research presented above denote that public actions related to development in a sustainable way should be initiated as soon as possible in the region of the Brígida river basin, in order to reduce the susceptibility of the territory to the desertification process.
Therefore, $\mathrm{AI}_{\mathrm{ASD}}$ can be used, which evaluates through precipitation and evapotranspiration data, susceptibility to desertification, and may be a valuable tool for monitoring by public and private agencies.

\section{Comparison analysis of the drought indices and aridity}

From a practical point of view, that is, using the data availability criteria, without taking into account statistical analysis it is possible to say that all indices used in the Brígida river basin are useful tools for monitoring drought and aridity. Besides, all indices were fully applied, without limitation of calculation, because the climatic data were available for the study region

However, in general, analysing the practical point of view, the unavailability of variety of climatic data, it is possible to say that the RAI and MIA methods are the most appropriate for drought and aridity analysis respectively at any location, because both used the most common available data.

But, if the study region has a variety of historical data, it is recommended the use of the PDSI for drought analysis, because it is a more complex method, which takes into account several factors, which directly relate to hydrological evaluation. Similarly, that the use of $\mathrm{AI}$ or $\mathrm{AI}_{\mathrm{ASD}}$ to assess aridity, because both methods employ precipitation and evapotranspiration data, the latter being extremely important for territories located in semi-arid regions.

The semi-arid regions, according to Moura et al. (2007) are characterized by strong heatstroke, high temperatures, irregular rainfall regime and concentrated in a short period, associated with high evapotranspiration rates. Thus, the use of drought and aridity indices that use a greater amount of data, which directly relate to climatic factors, can support more accurate and reliable results, serving as a tool for resource management water and desertification control.

\section{Statistical analysis}

\section{Drought indices}

Statistical analysis through the Tukey Test for the means of drought indices (Table 22) revealed that in the months of January to July and November to December, treatment 7 (PDSI) showed statistical difference when compared to other treatments - 2 to 6 (SPI), which did not differ significantly from each other. It is believed that this result is due to the fact that the PDSI is a more complex method when compared to other drought indices (RAI and SPI), as it employs in addition to precipitation data, evapotranspiration, recharging, flow and loss of soil moisture to your estimate.

In August, September and October treatment 1 (RAI) showed statistical difference when compared to treatment 7 (PDSI) and other treatments - 2 to 6 (SPI), which did not differ significantly from each other. This result is probably justified because the months of August, September and October are the driest months in the Brígida region, according to data from the Normal Climatological. This confirms the importance of dry and humid period analysis for hydrological studies of a given basin, as well as indicates 
Temporal trend of drought and aridity indices in semi-arid pernambucano to determine susceptibility to desertification

Table 22. Statistical analysis of the Tukey test for the averages of the dry indices.

\begin{tabular}{|c|c|c|c|c|c|c|c|c|c|c|c|c|}
\hline 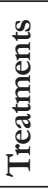 & JAN & FEB & MAR & APR & MAY & JUN & JUL & AUG & SEP & OCT & NOV & DEC \\
\hline 1 & $-0.4501 \mathrm{~b}$ & $-0.19862 \mathrm{~b}$ & $-0.20114 b$ & $-0.47483 \mathrm{~b}$ & $-0.5753 \mathrm{~b}$ & $-0.63402 \mathrm{~b}$ & $-0.59994 \mathrm{~b}$ & $-0.91836 \mathrm{a}$ & $-1.21691 \mathrm{a}$ & $-1.01375 \mathrm{a}$ & $-0.5303 \mathrm{~b}$ & $-0.46562 \mathrm{~b}$ \\
\hline 2 & $-0.00222 \mathrm{~b}$ & $-0.00039 \mathrm{~b}$ & $0.00053 \mathrm{~b}$ & $0.00012 \mathrm{~b}$ & $0.00002 \mathrm{~b}$ & $-0.00024 \mathrm{~b}$ & $0.00086 \mathrm{~b}$ & $0.00089 \mathrm{c}$ & $-0.01911 \mathrm{c}$ & $-0.04862 \mathrm{c}$ & $-0.03489 \mathrm{~b}$ & $-0.00764 \mathrm{~b}$ \\
\hline 3 & $0.00007 \mathrm{~b}$ & $0.00096 \mathrm{~b}$ & $-0.00026 \mathrm{~b}$ & $0.00017 \mathrm{~b}$ & $0.00017 \mathrm{~b}$ & $0.00001 \mathrm{~b}$ & $-0.00012 \mathrm{~b}$ & $-0.00019 \mathrm{c}$ & $-0.00018 \mathrm{c}$ & $-0.00001 \mathrm{c}$ & $0.00028 \mathrm{~b}$ & $-0.00011 b$ \\
\hline 4 & $0.00015 \mathrm{~b}$ & $0.00027 \mathrm{~b}$ & $0.00004 \mathrm{~b}$ & $0.00018 \mathrm{~b}$ & $0.00036 \mathrm{~b}$ & $0.00024 \mathrm{~b}$ & $0.00009 \mathrm{~b}$ & $0.00009 \mathrm{c}$ & $0.0001 \mathrm{c}$ & $0.0002 \mathrm{c}$ & $0.00016 \mathrm{~b}$ & $-0.0002 \mathrm{~b}$ \\
\hline 5 & $0.00043 \mathrm{~b}$ & $0.00047 \mathrm{~b}$ & $0.00034 \mathrm{~b}$ & $0.00042 \mathrm{~b}$ & $0.00047 \mathrm{~b}$ & $0.00043 \mathrm{~b}$ & $0.0004 \mathrm{~b}$ & $0.00041 \mathrm{c}$ & $0.00041 \mathrm{c}$ & $0.00046 \mathrm{c}$ & $0.00036 \mathrm{~b}$ & $0.00034 \mathrm{~b}$ \\
\hline 6 & $0.00043 \mathrm{~b}$ & $0.00059 \mathrm{~b}$ & $0.0004 \mathrm{~b}$ & $0.00047 \mathrm{~b}$ & $0.00052 \mathrm{~b}$ & $0.00049 \mathrm{~b}$ & $0.00045 \mathrm{~b}$ & $0.00046 \mathrm{c}$ & $0.00046 \mathrm{c}$ & $0.00051 \mathrm{c}$ & $0.00047 \mathrm{~b}$ & $0.00052 \mathrm{~b}$ \\
\hline 7 & $-5.81513 \mathrm{a}$ & $-3.92524 \mathrm{a}$ & $-1.33564 a$ & $-4.96505 \mathrm{a}$ & $-5.87731 \mathrm{a}$ & $-6.86455 \mathrm{a}$ & $-7.45598 \mathrm{a}$ & $-8.58406 \mathrm{~b}$ & $-8.37621 \mathrm{~b}$ & $-6.75809 \mathrm{~b}$ & $-7.00738 \mathrm{a}$ & $-6.72485 a$ \\
\hline
\end{tabular}

Treatment 1 = Rainfall Anomaly Index (RAI); Treatment 2 = Standardized Precipitation Index (SPI) accumulated in 6 months; Treatment 3 = Standardized Precipitation Index (SPI) accumulated in 12 months; Treatment $4=$ Standardized Precipitation Index (SPI) accumulated in 24 months; Treatment $5=$ Standardized Precipitation Index (SPI) accumulated in 36 months; Treatment $6=$ Standardized Precipitation Index (SPI) accumulated in 48 months; Treatment $7=$ Palmer Drought Severity Index (PDSI). Averages followed by the same letters in the column do not differ statistically from each other by the Tukey test at $5 \%$ probability.

Table 23. Statistical analysis of the Tukey test for the averages of the aridity indices.

\begin{tabular}{|c|c|c|c|c|c|c|c|c|c|c|c|c|}
\hline 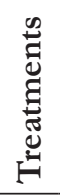 & JAN & FEB & MAR & APR & MAY & JUN & JUL & AUG & SEP & OCT & NOV & DEC \\
\hline 8 & $29.68374 b$ & $32.55997 \mathrm{~b}$ & $44.48714 \mathrm{~b}$ & $27.30692 \mathrm{~b}$ & $10.52385 \mathrm{~b}$ & $4.58909 \mathrm{~b}$ & $3.537108 \mathrm{~b}$ & $1.240406 \mathrm{~b}$ & $1.485797 \mathrm{~b}$ & $3.928926 \mathrm{~b}$ & $10.00747 \mathrm{~b}$ & $20.30583 \mathrm{~b}$ \\
\hline 9 & $48.62154 \mathrm{a}$ & $61.64272 \mathrm{a}$ & $81.10747 \mathrm{a}$ & $60.76616 \mathrm{a}$ & $24.39913 \mathrm{a}$ & $11.63824 \mathrm{a}$ & $7.897361 \mathrm{a}$ & $2.336029 \mathrm{a}$ & $2.570431 \mathrm{a}$ & $6.180961 \mathrm{a}$ & $15.92445 \mathrm{a}$ & $31.10277 \mathrm{a}$ \\
\hline 10 & $0.48616 \mathrm{c}$ & $0.6164 \mathrm{c}$ & $0.81103 \mathrm{c}$ & $0.60758 \mathrm{c}$ & $0.24391 \mathrm{c}$ & $0.11641 \mathrm{c}$ & $0.079084 \mathrm{c}$ & $0.023379 \mathrm{c}$ & $0.02563 \mathrm{c}$ & $0.061748 \mathrm{c}$ & $0.15933 \mathrm{c}$ & $0.31099 \mathrm{c}$ \\
\hline
\end{tabular}

Treatment 8 = Martonne's Aridity (MIA); Treatment $9=$ Thornthwaite's Aridity (AI); Treatment $10=$ Aridity Index of Areas Susceptible to Desertification $\left(\mathrm{AI}_{\mathrm{ASD}}\right)$. Averages followed by the same letters in the column do not differ statistically from each other by the Tukey test at $5 \%$ probability.

that statistically the RAI method (treatment 1) would be more sensitive to precipitation anomaly issues when compared to other treatments (2 to 7 ).

In the Tukey Test it was also observed that in the SPI method (treatments 2 to 6 ) regardless of the number of months accumulated $(6,12,24,36$ or 48$)$, the results did not differ statistically from each other. That is, the behaviour of drought in the Brígida river basin was identified in the same way in all treatments (2 to 6), regardless of the number of months.

Thus, the statistical results of the Tukey Test suggest that for the evaluation of drought in the Brígida river basin, the PDSI adjusted better when compared to other treatments, and that in the absence of this method, the RAI could be used without prejudice to the analysis. In addition, statistics suggest that if the use of PDSI or RAI is not possible, SPI may be used with any of the types of months accumulated (6, 12, 24, 36 and 48) as alternative tools for drought assessment in the Brígida river basin, and the susceptibility to desertification.

\section{Aridity indices}

The statistical analysis of the Tukey Test for the means of aridity indices (Table 23) suggested that in all months of the year, treatment 9 (AI) presented statistical difference when compared to other treatments. The Tukey Test also indicated that the 03 (three) methods employed (MIA, AI, $\mathrm{AI}_{\mathrm{ASD}}$ ) for analysis of aridity in the Brígida river basin differed statistically.
This implies saying that according to the Tukey Test, for the evaluation of aridity in the Brígida river basin, AI has adjusted better compared to other treatments (MIA and $\left.\mathrm{AI}_{\mathrm{ASD}}\right)$. In addition, when it is not possible to use AI can be adopted as a method MIA, and if not possible, $\mathrm{AI}_{\mathrm{ASD}}$ may be used to assess aridity in the study region and susceptibility to desertification without loss of reliability of the results.

\section{CONCLUSIONS}

In general, in the analyses of drought (RAI, PDSI and $\mathrm{SPI}$ ) and aridity indices (MIA, AI and $\mathrm{AI}_{\mathrm{ASD}}$ ) it was observed that in the period 1991-2016 had an increase in the number of records in the categories that refer to drought and aridity, and also a decrease in the values categorized as wet. That is, there was the intensification of droughts and aridity in the region of the Brígida river basin, and consequently increased susceptibility to desertification over the years.

In addition, the climatic trend assessment of drought indices (RAI, PDSI and SPI) and aridity (MIA, AI and $\mathrm{AI}_{\mathrm{ASD}}$ ) was observed using the TREND software, the occurrence of statistical significance among the values of the period 1991-2016 compared to those of 1961-1990, inferring that the last years of the historical series are drier, and aridity evolving.

Believed that these changes found are due to the reduction of precipitation, associated with temperature rise and evapotranspiration, in the region of the São Francisco river basin where the study area is tributary sub-basin. This fact is quite 
worrying, as it may contribute considerably, in the medium and long term to the acceleration of the desertification process, and consequently in the loss of productive land for irrigation in the Brígida river basin, harming the local subsistence.

This premise requires the continuous monitoring of extreme hydrological events, such as droughts and droughts, as well as the monitoring of climate change that can directly interfere in the hydrological cycle and consequently accelerate the process of desertification, on a micro scale (basin), or macro scale (region, state, country).

In this sense, all the methods tested (RAI, PDSI, SPI, MIA, $\mathrm{AI}$ and $\mathrm{AI}_{\mathrm{ASD}}$ ) were reliable from a practical and statistical point of view for the evaluation of drought and aridity in the Brígida river basin, as well as analysis of the progression of susceptibility to desertification.

However, it is important to emphasize that from the practical point of view some peculiarities were noted when comparing the methods with each other, such as the RAI and the SPI require only precipitation, as input data. On the other hand, the PDSI requires a wide variety of data (rain, evapotranspiration, recharging, soil moisture, etc.) as input data; and the SPI requires a series with an extended period of at least 30 years. Allied to this, MIA, AI and $\mathrm{AI}_{\mathrm{ASD}}$ are easily estimated, however, the latter two require evapotranspiration data that is not always available in climate data collection.

On the other hand, from the statistical point of view, it was found that the RAI and the PDSI were more appropriate to dry analysis, while the AI showed better adjustment for analysis of aridity and susceptibility to desertification in the Brígida river basin.

These results are important, as they demonstrate the possibility of alternative methods for the monitoring of drought and aridity in the study area, as well as the susceptibility to desertification, especially in places with lack of climatic data, such as semi-arid regions.

The trends observed in the study area show interesting notes, such as the need for investments in water infrastructure and sanitation by the managing bodies, since the increase in dry periods is occurring. Since it is essential, therefore, the implementation of management systems, which increase the efficiency of water distribution systems, avoid evaporation losses in the dams, as well as environmental education measures for the conscious use of water, associated with reuse policies.

Similarly, make investments, mainly for the replacement of conventional irrigation methods by others with lower water consumption, the implementation of the collection for the use of water and effectiveness of the water user registration.

Combined with this, the installation of sewage systems, for the proper treatment of effluents, and minimization of pollution of water bodies, which may affect availability in terms of quality and quantity in the medium and long term, harming, therefore not only current generations, but future ones.

Associated with these measures, expand the climate monitoring network supporting the development of research to investigate the origin of the increase in dry periods, reduction of wet periods, evolution of evapotranspiration, temperature, among others factors that are directly related to the effects of climate change, and which can trigger the process of desertification.
In this context, studies, such as that of the Brígida river are relevant, as they can serve as a model for other areas with similar characteristics. Mainly because the occurrence of the reduction of wet periods and growth of dry periods, as well as increased susceptibility to desertification is not an isolated condition in only one given locality, watershed or region.

This trend is a situation that has become frequent in various parts of the world, and that suggests a direct relationship with climate change, and therefore needs to be carefully investigated and monitored.

\section{REFERENCES}

Agência Estadual de Planejamento e Pesquisas de Pernambuco CONDEPE. Superintendência de Desenvolvimento do NordesteSUDENE. Instituto de Desenvolvimento de Pernambuco. Empresa Pernambucana de Pesquisa Agropecuária. (1987). Zoneamento Pedoclimático do Estado de Pernambuco. Recife: CONDEPE/SUDENE.

Agência Nacional de Águas - ANA. (2012). Diretrizes e análises recomendadas para a consistência de dados pluviométricos (18 p.). Brasília: ANA.

Agência Nacional de Águas - ANA. (2017). Sistema de Informações Hidrológicas: HidroWeb. Brasília: ANA. Retrieved in 2017, February 1, from http://www.snirh.gov.br/hidroweb/

Ahmed, K., Shahid, S., Wang, X., Nawaz, N., \& Khan, N. (2019). Spatiotemporal changes in aridity of Pakistan during 1901-2016. Hydrology and Earth System Sciences, 23(7), 3081-3096. http:/ /dx.doi. org/10.5194/hess-23-3081-2019.

Araújo, S. M. S. (2004). Opólo gesseiro do Araripe: unidades geoambientais e impactos da mineração [Tese de doutorado]. Universidade Estadual de Campinas, Campinas.

Azevedo, J. R. G. (2017). Software para preenchimento de falbas. Recife: UFPE.

Braga, A. C. F. M., Pontes Filho, J. D. A., \& Braga, C. F. C. (2015). SPI como ferramenta para a gestão dos recursos hídricos: estudo de caso da bacia do rio Piranhas-Açu. In Anais do XXI Simpósio Brasileiro de Recursos Hidricos. Brasília: ABRH.

Brasil. Ministério da Integração Nacional - MIN. (2005). Nova delimitação do semiárido brasileiro: Portaria no 89 de 16 de março de 2005 (35 p.). Brasília: MIN.

Brasil. Ministério das Minas e Energia. Departamento Nacional de Produção Mineral - DNPM. (2009). Mineração no semiárido brasileiro (200 p.). Brasília: DNPM.

Brasil. Ministério do Meio Ambiente - MMA. (2007). Atlas das áreas susceptiveis à desertificação do Brasil (134 p.). Brasília: MMA.

Brasil. Ministério do Meio Ambiente - MMA. (2012). Resoluções do CONAMA: 1984-2012 (1126 p.). Brasília: MMA. 
Buriti, C. O., \& Barbosa, H. A. (2018). Um século de secas: por que as políticas hidricas não transformam o semiárido brasileiro (434 p.). Portugal: Chiado.

Cândido, D. H., \& Nunes, L. H. (2008). Influência da orografia na precipitação da área entre o vale do rio Tietê e a Serra da Mantiqueira. GEOUSP Espaço e Tempo, 1(24), 8-27. http:/ / dx.doi. org/10.11606/issn.2179-0892.geousp.2008.74094.

Centro de Gestão e Estudos Estratégicos - CGEE. (2016). Desertificação, degradação da terra e secas no Brasil (252 p.). Brasília: CGEE.

Centro de Previsão de Tempo e Estudos Climáticos - CPTEC. (2017). Condições da última semana: condições de neutralidade no pacífico equatorial. Brasília: CPTEC. Retrieved in 2017, November 12, from http://enos.cptec.inpe.br/\#

Chiew, F., Siriwardena, L., Arene, S., \& Rahman, J. (2017). TREND detection software. Canberra: CRC for Catchment Hydrology's (CRCCH) Climate Variability Program. Retrieved in 2017, January 10, from www.toolkit.net.au/trend

Chowdhury, A. I. (2018). Assessment of intensity and distribution of aridity over Bangladesh using different climate índices with GIS. Climatic Change, 4(16), 743-749.

Conti, J. B. (2005). A questão climática do Nordeste brasileiro e os processos de desertificação. Revista Brasileira de Climatologia, 1(1), 7-14.

Costa, J. A., \& Rodrigues, G. P. (2017). Space-time distribution of rainfall anomaly index (RAI) for the Salgado Basin, Ceará State - Brazil. Revista Ciência e Natura, 39(3), 627-634. http://dx.doi. org/10.5902/2179460X26080.

Dabaghi, M., \& Manjari, K. G. A. (2017). The climate survey of Razan-Qahavand Plain Through de-Martonne Aridity Index. International Journal of Engineering Science, 6(9), 49-60.

Dantas, M. E., Ferreira, R. V., Shinzato, E., Brandão, R. L., Teixeira, W. G., \& Freitas, L. C. (2018). A geodiversidade da Chapada do Araripe: de Padre Cícero a Luiz Gonzaga. In Anais do $12^{\circ}$ Simpósio Nacional de Geomorfologia. Crato: CPRM.

Empresa Brasileira de Pesquisa Agropecuária - EMBRAPA. (2016). Clima. Brasília: EMBRAPA. Retrieved in 2017, February 1, from https://www.cnpf.embrapa.br/pesquisa/efb/clima.htm

Eshetu, G., Johansson, T., \& Garedew, W. (2016). Rainfall trend and variability analysis in Setema-Gatira area of Jimma, Southwestern Ethiopia. African Journal of Agricultural Research, 11(32), 3037-3045. http://dx.doi.org/10.5897/AJAR2015.10160.

Faeirstein, G. V. M. (2019). Avaliação do indice de severidade de seca de Palmer (PDSI) através de planilha eletrônica [Trabalho de conclusão de curso]. Centro de Tecnologia e Geociências, Universidade Federal de Pernambuco, Recife.
Faro, G. T. C., Garcia, J. I. B., Oliveira, C. P. M., \& Ramos, M. R. S. (2019). Application of indices for water resource systems stress assessment. Revista Brasileira de Recursos Hídricos, 24(e7), 1-13. http:/ /dx.doi.org/10.1590/2318-0331.241920180106.

Fechine, J. A. L., \& Galvíncio, J. D. (2014). Uma forma de convivência com a seca: bacia hidrográfica do Rio Brígida - Pernambuco Brasil. Revista Brasileira de Geografia Física, 7(4), 724-730. http:// dx.doi.org/10.5935/1984-2295.20140009.

Felix, V. S. (2015). Análise de 40 anos de precipitação pluviométrica da bacia hidrográfica do Rio Espinharas - PB. Revista Brasileira de Geografia Física, 8(5), 1347-1358. http:/ /dx.doi.org/10.5935/19842295.20150073.

Fundação Oswaldo Cruz - FIOCRUZ. (2017). Vulnerabilidade a mudança do clima. Recife: FIOCRUZ. Retrieved in 2020, January 6, from https://projetovulnerabilidade.fiocruz.br/noticias/103seminario-23

Ganem, R. S. (2017). Caatinga: estratégias de conservação (105 p.). Brasília: Câmara dos Deputados. Retrieved in 2020, January 10, from http://bd.camara.gov.br/bd/handle/ bdcamara/34479

Gao, Y., Li, X., Leung, L. R., Chen, D., \& Xu, J. (2015). Aridity changes in the Tibetan Plateau in a warming climate. Environmental Research Letters, 10(034013), 034013. http://dx.doi.org/10.1088/17489326/10/3/034013.

Granja, C. V. A., Cavalcante, E. P., Caffé Filho, H. P., Siqueira, M. S., \& Nascimento, W. (2017). Degradação ambiental: exploração de gipsita no Polo Gesseiro do Araripe. Revista Multidisciplinar e de Psicologia, 11(36), 239-267. http://dx.doi.org/10.14295/idonline. v11i36.782.

Gross, J. A., \& Cassol, R. (2015). Ocorrências de índices de anomalia de chuva negativos no estado do Rio Grande do Sul. Revista Geografia Acadêmica, 9(2), 21-33. http://dx.doi.org/10.18227/16787226rga.v9i2.3012.

Guenang, G. M., \& Kamga, F. M. (2014). Computation of the Standardized Precipitation Index (SPI) and its use to assess drought occurrences in Cameroon over recent decades. Journal of Applied Meteorology and Climatology, 53(10), 2310-2324. http:// dx.doi.org/10.1175/JAMC-D-14-0032.1.

Hargreaves, G. H., \& Christiansen, J. E. (1974). Production as a function of moisture availability. ITCC Review III, 9, 179-189.

Instituto Brasileiro de Geografia e Estatística - IBGE. (2010). Censo demográfico 2010. Rio de Janeiro: IBGE. Retrieved in 2020, March 31, from https:// censo2010.ibge.gov.br/

Instituto Nacional de Meteorologia - INMET. (2009). Normais climatológicas do Brasil: 1961-1990 (465 p.). Brasília: INMET.

Instituto Nacional de Meteorologia - INMET. (2017). Banco de Dados Meteorológicos para Ensino e Pesquisa (BDMEP). Brasília: INMET. 
Retrieved in 2017, December 4, from http:/ / www.inmet.gov.br/ portal/index.php?r=bdmep/bdmep

Intergovernmental Panel on Climate Change - IPCC. (2014). Climate Change 2014: impacts, adaptation, and vulnerability - part B: regional aspects. Contribution of Working Group II to the Fifth Assessment Report of the Intergovernmental Panel on Climate Change (688 p.). New York: IPCC.

Intergovernmental Panel on Climate Change - IPCC. (2019). Desertification (Chap. 3, 174 p.). Switzerland: IPCC.

Jesus, J. B., Souza, B. B., Oliveira, A. M. S., \& Gama, D. C. (2019). Aridity index and climatic risk of desertification in the semi-arid state of Sergipe. Revista Brasileira de Climatologia, 24, 214-227. http:/ / dx.doi.org/10.5380/abclima.v24i0.62847.

Koudahe, K., Kayode, A. J., Samson, A. O., Adebola, A. A., \& Djaman, K. (2017). Trend analysis in standardized precipitation index and standardized anomaly index in the context of climate change in Southern Togo. Atmospheric and Climate Science, 7(04), 401-423. http:/ /dx.doi.org/10.4236/acs.2017.74030.

Limeira, R. C., Azevedo, P. V., Bezerra, W. A., \& Almeida, M. V. (2006). Índice de severidade de seca de Palmer para localidades representativas das microrregiões do litoral e sertão do estado da Paraíba. In Anais do XIV Congresso Brasileiro de Meteorologia. Florianópolis: CBMET.

Lins, F. A. C., Silva, J. L. B., Moura, G. B. A., Ortiz, P. F. S., Oliveira, J. D. A., \& Alves, M. V. C. (2017). Quantile technique to precipitation, rainfall anomaly index and biophysical parameters by remote sensing in Serra Talhada, Pernambuco. Journal of Hyperspectral Remote Sensing, 7(6), 334-344. http://dx.doi.org/10.29150/jhrs.v7.6.p334-344.

Lopes, I., \& Leal, B. G. (2015). Índice de aridez e tendência a desertificação para estações meteorológicas nos estados da Bahia e Pernambuco. Revista Brasileira de Climatologia, 17, 155-172. http:/ / dx.doi.org/10.5380/abclima.v17i0.42413.

Lucena, R. L., Cabral Júnior, J. B., \& Steinke, E. T. (2018). Comportamento Hidroclimatológico do Estado do Rio Grande do Norte do Município de Caicó. Revista Brasileira de Meteorologia, 33(3), 485-496. http://dx.doi.org/10.1590/0102-7786333008.

Mainguet, M. (1998). Aridity: droughts and buman development. New York: Springer.

Maliva, R., \& Missimer, T. (2012). Arid lands water evaluation and management. Berln: Environmental Science and Engineering. http:/ / dx.doi.org/10.1007/978-3-642-29104-3.

Marengo, J. A. (2008). Vulnerabilidade, impactos e adaptação à mudança do clima no semiárido do Brasil. Parcerias Estratégicas, 13(27), 149-176.

Martonne, E. (1926). Aréisme et Indice d'aridité. Comptes Rendus de L'Academy des Sciences, 182, 1395-1398.
McKee, T. B., Doesken, N. J., \& Kleist, J. (1993). The relationship of drought frequency and duration to time scales. In Proceedings of the 8th Conference on Applied Climatology. (pp. 179-184). Anaheim, California: American Meteorological Society.

Mendes, P. P. (1999). Estatística aplicada a aquicultura (265 p.). Recife: Bagaço.

Moral, F. J., Paniagua, L. L., Rebollo, F. J., \& García-Martín, A. (2017). Spatial analysis of the annual and seasonal aridity trends in Extremadura, southwestern Spain. Theoretical and Applied Climatology, 130(3-4), 917-932. http:/ /dx.doi.org/10.1007/s00704-016-1939-y.

Moura, M. S. B., Galvincio, J. D., Brito, L. T. L., Souza, L. S. B., Sá, I. I. S., \& Silva, T. G. F. (2007). Clima e água de chuva no Semi-Árido (59 p.). Petrolina: EMBRAPA Semiárido.

Muhire, I., \& Ahmed, F. (2016). Spatiotemporal trends in mean temperatures and aridity index over Rwanda. Theoretical and Applied Climatology, 123(1-2), 399-414. http://dx.doi.org/10.1007/s00704014-1353-2.

Oliveira, G. S. (2001). O El Niño e você: o fenômeno climático (116р.). São Paulo: Transtec.

Palmer, W. C. (1965). Meteorological drought. Research Paper, (45), 1-65.

Pernambuco. Secretaria de Ciência, Tecnologia e Meio Ambiente - SECTMA. (1998). Plano Estadual de Recursos Hidricos de Pernambuco - PERH-PE. Recife: SECTMA.

Pernambuco. Secretaria de Ciência, Tecnologia e Meio Ambiente - SECTMA. (2006). Atlas de bacias hidrográficas de Pernambuco. Recife: SECTMA.

Pramudya, Y., Onishi, T., Senge, M., Hiramatsu, K., \& Nur, P. M. R. (2019). Evaluation of recent drought conditions by standardized precipitation index and potential evapotranspiration over Indonesia. Paddy and Water Environment, 17(3), 331-338. http:/ / dx.doi.org/10.1007/s10333-019-00728-z.

Ribeiro, S. K., \& Santos, A. S. (Eds.). (2016). Mudanças climáticas e cidades: relatório especial do painel brasileiro de mudanças climáticas (116 p.). Rio de Janeiro: PBMC, COPPE-UFRJ.

Rodrigues, D. F. B., Montenegro, S. M. G. L., Villar, A. C., Gusmão, L., Araújo, D. C. S., \& Ursulino, B. S. (2018). Caracterização do índice de severidade da seca de palmer na bacia do Rio Pajeú - PE utilizando computação em nuvem. In Anais do XIV Simpósio de Recursos Hidricos do Nordeste. Maceió: ABRH, .

Rooy, M. P. V. (1965). A rainfall anomaly index independent of time and space. Notos, 14, 43-48.

Rossato, L., Marengo, J. A., Angelis, C. F., Pires, L. B. M., \& Mendiondo, E. M. (2017). Impact of soil moisture over Palmer Drought Severity Index and its future projections in Brazil. 
Revista Brasileira de Recursos Hídricos, 22(0), e36. http://dx.doi. org/10.1590/2318-0331.0117160045.

Sá, I. I. S., Moura, M. S. B., Barbosa, L. F. S., Silvas, T. G. F., \& Galvíncio, J. D. (2010). Influência dos cenários de mudanças climáticas na evapotranspiração potencial da bacia hidrográfica do Sub-médio São Francisco. In J. D. Galvíncio (Ed.), Mudanças climáticas e impactos ambientais (Cap. 7, pp. 133-144). Recife: Ed. Universitária da UFPE.

Sampaio, J. C. L., \& Pinto, É. J. A. (2018). Análise da estiagem de um dos principais reservatórios da região metropolitana de Belo Horizonte. In Anais do XIV Simpósio de Recursos Hídricos do Nordeste. Maceió: ABRH.

Santos, F. D. A., Mendes, L. M. S., \& Cruz, L. M. B. (2018). Análise do índice de aridez da bacia hidrográfica do rio Piracuruca - Ceará - Piauí, Nordeste do Brasil. Revista Geosul, 33(67), 181-199. http:/ / dx.doi.org/10.5007/2177-5230.2018v33n67p181.

Silva, I. P., \& Silva, J. A. A. (2003). Métodos estatísticos aplicados à pesquisa cientifica: uma abordagem para profissionais da pesquisa agropecuária (305 p.). Recife: UFRPE.

Silveira, S. C. R., Teixeira-Gandra, C. F. A., Damé, R. C. F., Lemos, G. S., Weymar Junior, L. C. N., Karsburg, R. M., Tavares, M. A. R., Cadoná, E. A., Couto, R. S., Nunes, G. S., Klumb, G. B., \& Moraes, P. (2017). Índice de severidade de seca de Palmer utilizando metodologias indiretas para a estimativa da evapotranspiração de referência para Pelotas/ RS. In Anais do XXII Simpósio Brasileiro de Recursos Hídricos. Florianópolis: ABRH.

Souza, I. F., Azevedo, P. V., Silva, V. P. R., \& Queiroz, M. G. (2010). Tendência climática do Índice de aridez do estado de Pernambuco, Brasil. In Anais do XVI Congresso Brasileiro de Meteorologia. Belém: SBMET.
Thornthwaite, C. W. (1948). An approach toward a rational classification of climate. Geographical Review, 38(1), 55-94. http:// dx.doi.org/10.2307/210739.

Tucci, C. E. M. (2013). Hidrologia: ciência e aplicação (943 p.). Porto Alegre: ABRH.

United Nations Convention to Combat Desertification - UNCCD. (2014). Desertification: the invisible frontline (20 p.). Germany: UNCCD.

United Nations Educational, Scientific and Cultural Organization - UNESCO. (1979). Map of the world distribution of arid regions: explanatory note (MAB Technical Notes, No. 7, pp. 1-53). Paris: UNESCO.

Universidade Federal de Santa Catarina - UFSC. Centro de Estudos e Pesquisas em Engenharia e Defesa Civil - CEPED. (2015). 1583/2012: histórico de secas no Nordeste do Brasil. Florianópolis: CEPED. Retrieved in 2017, November 10, from http://www. ceped.ufsc.br/historico-de-secas-no-nordeste-do-brasil/

World Meteorological Organization - WMO. (1989). Calculation of monthly and annual 30-year standard normals (WMO Technical Document, No. 341, WCDP (Series), No. 10, 13 p.). Geneva: WMO.

World Meteorological Organization - WMO. (2012). Standardized precipitation index: user guide (WMO Technical Document, No. 1090, 24 p.). Geneva: WMO.

\section{Authors contributions}

Fabianny Joanny Bezerra Cabral da Silva: Contributed to the idealization, analysis of the data, development of the study and writing of the manuscript.

José Roberto Gonçalves de Azevedo: Contributed intellectually to the writing of the manuscript and interpretation of the data. 